William \& Mary Law School

William \& Mary Law School Scholarship Repository

Spring 2019

\title{
From Stele to Silicon: Publication of Statutes, Public Access to the Law, and the Uniform Electronic Legal Material Act
}

Frederick W. Dingledy

William \& Mary Law School, fwding@wm.edu

Follow this and additional works at: https://scholarship.law.wm.edu/libpubs

Part of the Law Librarianship Commons, and the Legislation Commons

\section{Repository Citation}

Dingledy, Frederick W., "From Stele to Silicon: Publication of Statutes, Public Access to the Law, and the Uniform Electronic Legal Material Act" (2019). Library Staff Publications. 133.

https://scholarship.law.wm.edu/libpubs/133

Copyright c 2019 by the authors. This article is brought to you by the William \& Mary Law School Scholarship Repository.

https://scholarship.law.wm.edu/libpubs 


\title{
From Stele to Silicon: Publication of Statutes, Public Access to the Law, and the Uniform Electronic Legal Material Act ${ }^{\star}$
}

\author{
Frederick W. Dingledy ${ }^{* \star}$
}

For a legal system to succeed, its laws must be available to the public it governs. This article looks at the methods used by different governments throughout history to publicize legislation and the rulers' possible motivations for publication. It concludes by discussing how the Uniform Electronic Legal Material Act provides the next logical step in this long tradition of publicizing the law.

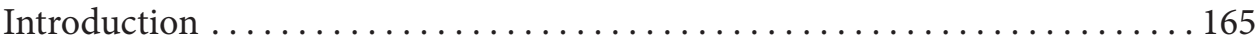

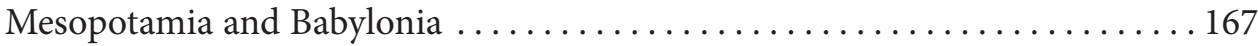

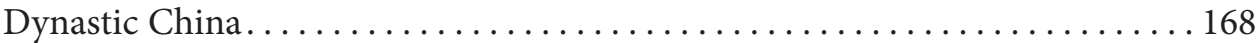

Ancient Greece . . . . . . . . . . . . . . . . . . . . . . . . . . . . . . . 170

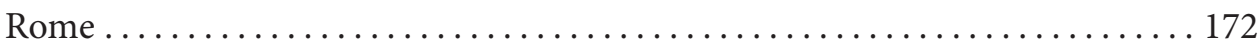

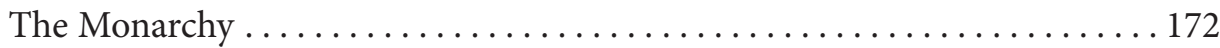

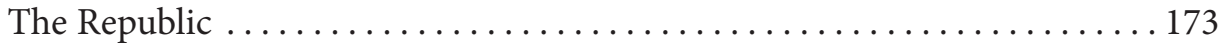

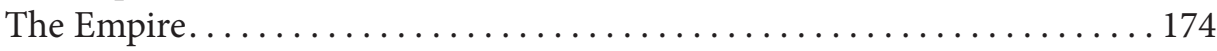

The Byzantine Empire and Justinian's Corpus Juris Civilis . . . . . . . . . . . . 177

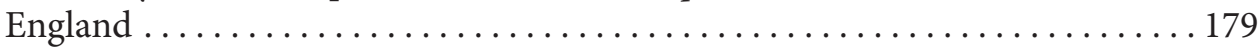

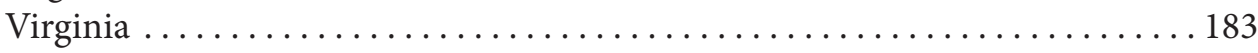

Modern Foreign and International Views $\ldots \ldots \ldots \ldots \ldots \ldots \ldots \ldots \ldots \ldots$

The U.S. Federal Government . . . . . . . . . . . . . . . . . . . . . . . . . . . 189

The Internet, Public Access to the Law, and UELMA . . . . . . . . . . . 192

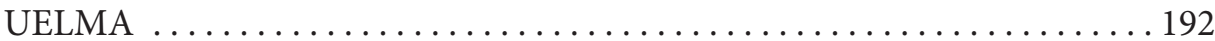

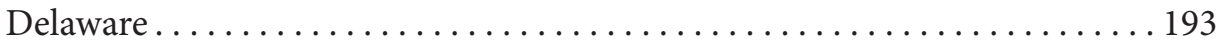

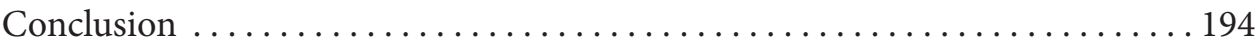

\section{Introduction}

The laws of a country are necessarily connected with every thing belonging to the people of it; so that a thorough knowledge of them, and of their progress, would inform us of every thing that was most useful to be known about them. ${ }^{1}$

* c c Frederick W. Dingledy, 2019.

** Senior Reference Librarian, William \& Mary Law School. The author would like to thank Benjamin J. Keele and Sunil Rao for their invaluable help.

1. 1 William Waller Hening, The Statutes at Large: Being a Collection of All the laws of Virginia i (photo. reprt. 1969) (1823), quoting 1 Joseph Priestley, Lectures ON History, and GENERAL Policy 155 (1793), https://archive.org/details/lecturesonhis00prie. 
I1 Roman Emperor Gaius Caesar, nicknamed Caligula, was never known for his good behavior. For one, he exhausted his entire inheritance of 27 million gold pieces in under a year. ${ }^{2}$ To replenish his treasury, Caligula imposed taxes on almost any conceivable good or service. Originally, many subjects did not pay the new taxes because information on them passed only by word of mouth. In response, Caligula posted a copy of the new laws in public - in a location so high and in print so tiny that no one could read them. ${ }^{3}$

I2 As Judge Jeffrey Sutton aptly noted about Caligula’s actions, deliberately hiding the letter of the law from a country's people is "not a good idea. . . . How can citizens comply with what they can't see?"4

I3 Legal philosopher Lon L. Fuller argues that a legal system can go awry in at least eight ways. Two are a failure to publicize the rules its subjects are expected to follow and a failure to make those rules understandable. ${ }^{5}$ Even if not many people actually read the published laws, Fuller says, publication is still important. People who read the law can help model the behavior of those who do not. Laws must be published so that they may be subject to public criticism. Publishing the law helps guard against ignorance by the officials sworn to uphold and enforce those laws. In addition, citizens are simply entitled to know the content of those laws, and the government cannot predict who will or will not read them. ${ }^{6}$

I4 The Internet era has made the act of publicizing the law easier in some aspects while adding new challenges. Electronic legal materials can be quickly distributed to many more people than printed matter. Traditionally, however, it was easier to know whether print laws were authentic and how recently they were updated. The same does not hold true for online resources; it can sometimes be hard to tell when content on a website was last updated or whether it was altered from the official version. The Uniform Law Commission drafted the Uniform Electronic Legal Material Act (UELMA) in 2011 to address this issue, creating a set of guidelines intended to make authenticated legal materials easily and permanently available to the public. ${ }^{7}$

I5 This article focuses on legislation and royal and imperial edicts as it looks at how different governments have publicized their laws throughout the ages. It begins with ancient Babylonia and Mesopotamia, then examines dynastic China, ancient Greece, ancient Rome, England, and Virginia, followed by a look at the state of published federal law in the United States today. The final part discusses UELMA and how one state has implemented it, and concludes by discussing how historical precedent calls for states to pass UELMA to continue the tradition of publishing laws into the electronic age.

2. Gaius Suetonius Tranquillius, The Twelve Caesars II IV.37 (Robert Graves trans., Penguin Books 1957).

3. Id. III IV.40-IV.41. The line between state funds and emperors' personal funds was blurry. Taxes that theoretically went to the state, such as the aurum coronarium that Caligula imposed, went directly to the emperor's purse. Fergus Millar, The Fiscus in the First Two Centuries, 53 J. Roman Stud. 29, 38-39 (1963).

4. Summa Holdings, Inc. v. Comm'r, 848 F.3d 779, 781 (6th Cir. 2017).

5. Lon L. Fuller, The Morality of Law 38-39 (rev. ed. 1969).

6. Id. at 51 .

7. Unif. Electronic Legal Material Act (UELMA) Prefatory Note (Unif. LaW Comm’n 2011). 


\section{Mesopotamia and Babylonia}

I6 Public relations, rather than public knowledge, may have inspired the earliest efforts at publicizing laws. Mesopotamian rulers Enmetena and Irikagina handed down edicts in the 25th to 24th centuries BCE that read more like a list of accomplishments than a set of prescriptions for citizens. ${ }^{8}$ As the 22 nd century BCE turned to the 21st, the founder of Mesopotamia's Third Dynasty of Ur had his Laws of UrNamma-the oldest code of law known to exist-engraved prominently into temple monuments throughout his kingdom. ${ }^{9}$ The Code of Hammurabi (King of Babylonia, r. ca. 1792-1750 BCE) was carved into a royal monument built with enough strength that it still survives today. ${ }^{10}$

I7 Hammurabi's Code is closer to the modern idea of a codification, ${ }^{11}$ as it collects judicial decisions (in the form of "person who does X will be punished by Y") and arranges them by subject. ${ }^{12}$ So far, though, little evidence suggests that Hammurabi's Code was cited in many trial documents or represented a complete statement of Babylonian law; anyone researching that era's rules had to consult numerous other legal documents to get a full picture. ${ }^{13}$ While some scholars view these early codes as efforts to codify existing law for the ease of administering justice, others opine that they were more akin to propaganda ${ }^{14}$ or scholarly compilations similar to pharmacopoeia. ${ }^{15}$

I8 Hammurabi's Code frequently featured in reading and writing lessons for centuries, ${ }^{16}$ but it may be a bit much to claim that the Code itself was a scholarly exercise. The idea that it served as a royal public relations exercise, on the other hand, makes sense. The main version of Hammurabi's Code that survived to modern times was inscribed on a monument called the Stele of Hammurabi. ${ }^{17}$ The Stele included an image of Hammurabi and Shamash, the Mesopotamian god of the sun and justice. ${ }^{18}$ A poetic prologue and epilogue describe Hammurabi's great accomplishments; how the gods chose him to deliver justice to Babylonia; how he inscribed these rules to protect the weak, orphans, and widows. Readers are then implored to remember Hammurabi's name. ${ }^{19}$ The Stele further asks future kings to preserve the justice Hammurabi handed down. ${ }^{20}$ One inscription advises anyone

8. Claus Wilcke, Mesopotamia: Early Dynastic and Sargonic Periods, in 1 A History OF ANCIENT NeAr EASTERn Law 141-43 (Raymond Westbrook ed., Brill Handbook of Oriental Studies Vol. 72-1, 2003) (e.g., Enmetena "let the child return to the mother . . . established the liberation of barley debts. ..."; Irikagina "cleared the prisons of indebted children of Lagaš. . ..").

9. Bertrand Lafont \& Raymond Westbrook, Mesopotamia: Neo-Sumerian Period (Ur III), in 1 A History of ANCIENT NeAr EASTERn LAw, supra note 8, at 183.

10. Kathryn E. Slanski, The Law of Hammurabi and Its Audience, 24 Yale J.L. \& Human. 97, 101-02 (2012).

11. See Codification, Black's LaW Dictionary (10th ed. 2014).

12. Slanski, supra note 10 , at 104.

13. Martha T. Roth, Law Collections from Mesopotamia and Asia Minor 4-5 (1995); Slanski, supra note 10, at 103.

14. Roth, supra note 13 , at 4-5.

15. Id.

16. Slanski, supra note 10 , at 103-04.

17. Id. at 97.

18. Id. at $105-06$.

19. Id. at $104,107$.

20. Id. at 109 . 
with a lawsuit to read the Stele, ${ }^{21}$ but scholars generally agree that only a very small class of elite society and scribes could do so. ${ }^{22}$ These factors imply that one of Hammurabi's main motivations for creating his Code was to glorify himself. The net effect, nevertheless, was to provide authenticity and some public accessibility to the law, as well as to preserve that law for future generations - three mandates that are reflected today in UELMA. ${ }^{23}$

\section{Dynastic China}

I9 Throughout much of China's history, two competing schools of thought, Confucianists and Legalists, argued over the importance of published law. On one side was $l i$, an unwritten code of proper behavior based on a person's status within society, somewhat like the ideas of ethics, morals, or chivalry. ${ }^{24}$ On the other was $f a$, published law, and the related concept of $x$ ing, punishment. ${ }^{25}$ To Confucianists, $l i$ was the proper way to govern; $f a$ was at most a stick to enforce $l i$. In their view, rule by li led to people with a proper sense of virtue and shame, while rule by $f a$ resulted in a populace who cared nothing for morals, only avoiding punishment. ${ }^{26}$

\10 Legalists, meanwhile, believed that $f a$ was government's most important tool. ${ }^{27}$ In their opinion, properly designed $f a$ discouraged misbehavior and reduced the need to actually exercise xing. ${ }^{28}$ They argued that $f a$ was better able than $l i$ to adapt to societal changes, educate the people, tear down old aristocratic privileges, and thereby create a prosperous, egalitarian society. ${ }^{29}$ The rise of a new landowning class, socially inferior to the ruling class, began $f a$ 's ascension during the Eastern Zhou dynasty (771-221 BCE). This new class wanted a say in government that $l i$ did not provide. ${ }^{30}$ In 536 BCE, the state of Zheng's prime minister, Zi Chan, ordered the creation of xing shu, "books of punishment," inscribed on a set of bronze tripods. ${ }^{31}$ These were followed a couple of decades later by xing shu inscribed on iron tripods in the state of Qin, and by a set of punishments written on bamboo by Deng Xi. ${ }^{32}$

21. Id. at 108 .

22. Michael Gagarin, Writing Greek Law 151 (2008). One of the inscriptions does advise anyone who cannot read the Stele to ask another person to read it aloud to him or her. Slanski, supra note 10, at 108. The author wonders how a person who could not read was expected to read this direction.

23. UELMA, supra note 7.

24. John W. Head \& Xing Lijuan, Legal Transparency in Dynastic China 11 (2013).

25. Id.

26. Id. at 114-15, quoting Zhang Zaoqun, Tenets of Rule by Li: A Study on the Confucian Ethical Code In the Han Dynasty 43-44 (Xing Lijuan trans. 2011).

27. HEAD \& LiJUAN, supra note 24 , at 119.

28. Id. at 124 .

29. Id. at $124-30$.

30. Id. at 43 .

31. John W. Head \& Yanping Wang, Law Codes in Dynastic China 48-51 (2005). There seems to be some disagreement as to whether the xing shu was the first publicly released collection of laws in China. Scholar Herrlee Glessner Creel argues that some rulers made their laws available to the public even earlier than 536 BCE. Id. at 52-56, citing Herlee Glessner Creel, Legal Institutions and Procedures during the Chou Dynasty, in Essays on ChinA's Legal Tradition 26, 34-37 (Jerome Alan Cohen et al. eds., 1980).

32. HEAD \& WANG, supra note 31 , at 56 . Xi was not authorized to publish rules and was eventually executed, but the state of Zheng adopted his "bamboo punishments" posthumously. Id. at 56-57. 
I11 Confucianists regained the upper hand during the Qin (221-206 BCE) and Han (206 BCE-220 CE) dynasties, but by then that school of thought concluded that li's rules needed to be codified and published, so the Legalists scored a partial win. ${ }^{33}$ Dynastic China would go on to create a series of codified, published laws, such as the Tang Code of $653 \mathrm{CE}$ and $737 \mathrm{CE},{ }^{34}$ the Song Code of $963,{ }^{35}$ various codes and statutes under the Mongols' Yüan dynasty (1279-1368), ${ }^{36}$ the Da Ming Lü (Great Ming Code) of 1389, ${ }^{37}$ and the Ta Ch'ing lü-li (Statutes and Sub-statutes of the Great Ch'ing, a.k.a. the Qing Code) of $1740 .{ }^{38}$ Unlike Hammurabi's Stele, the Chinese dynastic governments published these codes with public education in mind. From their point of view, a citizen needed to know what their duties were in order to comply with them.

I12 Literacy was an important part of dynastic Chinese culture-scholars refer to "a culture of reading" 39 and "a culture of written texts." ${ }^{0}$ The Song Dynasty reintroduced civil service exams to reduce the influence of Tang aristocrats, increasing the importance of literacy towards advancing in society. ${ }^{41}$ Readers were $d u s h u-a$ social status many considered a point of moral superiority. ${ }^{42}$ Potentially, a literate commoner could join the elite through success in the exams. ${ }^{43}$ It therefore seems reasonable to infer that the government would assume its public could read. That said, the portion of the public the rulers cared about may have been limited. The rise of printing technology in the Song era entrenched differences between social classes that would persist through several dynasties. ${ }^{44}$ Literacy became a marker of the elite. Printing presses caused China's literacy rate to rise substantially, ${ }^{45}$ but in the early 12 th century, only $0.005 \%$ of the empire's population successfully passed the exams, ${ }^{46}$ and many servants remained illiterate. ${ }^{47}$ Dynastic China's published codes may not have made the country's laws available to all who lived under them, but they still represent an important example of a ruling class who acted on the belief that a nation's laws should be known to more than just the laws' authors.

I13 China's long history of publishing laws influenced other nations. The Tang Code was, in a way, China's counterpart to Justinian's Corpus Juris Civilis, forming the basis of an ius commune for East Asian nations ${ }^{48}$ and influencing neighboring

33. Id. at $62-63$.

34. Id. at $105-36$.

35. Id. at 144 .

36. Id. at $151-73$.

37. Id. at $179-86$.

38. Id. at $192-211$.

39. Li Yu, "A History of Reading in Imperial China, 1000-1800", at $\$ 3.1$ (2003) (Ph.D. dissertation, Ohio State University) (available in ProQuest Dissertations and Theses database).

40. Timothy Brook, The Confusions of Pleasure: Commerce and Culture in Ming China 58 (1999).

41. Thomas H.C. Lee, Books and Bookworms in Song China: Book Collection and the Appreciation of Books, 25 J. Song-YuAng STUd. 193, 194-95 (1995); Yu, supra note 39, §\$ 1.5, 3.1.

42. Yu, supra note $39, \S 1.5$.

43. Thomas H.C. Lee, Government Education and Examinations in Sung China 20-21 (1985).

44. Brook, supra note 40, at 57-58; Lee, supra note 41, at 194-95.

45. LEE, supra note 43 , at 28-29.

46. Id. at 21 .

47. Id.

48. Marie Seong-Hak Kim, Introduction: Searching for the Spirit of Korean Law, in THE SpIRIT OF Korean Law 1, 3-4 (Marie Seong-Hak Kim ed., 2016). 
nations such as Japan and Korea. ${ }^{49}$ Japanese rulers committed laws to written form as early as the seventh century CE. ${ }^{50}$ During the early days of the Meiji Restoration (1867-1912), Japan's rapid period of Westernization, its rulers borrowed from Chinese legal tradition when enacting and publishing three legal codes that blazed the path towards European-style codifications. ${ }^{51}$ Korea's Chosŏn dynasty (1392-1910) built on the Great Ming Code to create its own published codes. ${ }^{52}$

I14 Just as in ancient Babylonia, dynastic China's codes provided the public with a way to access authentic copies of the law-copies that could be preserved for future generations. They may have been designed with a small elite population in mind but still spread the law to a wider audience. These codes, and the codes they inspired, represent another step toward the wide public availability of the law that UELMA envisions.

\section{Ancient Greece}

I15 The ancient Greeks wrote down laws for the sake of public access as early as the seventh century BCE. ${ }^{53}$ The first written laws were not complete codifications; many were solitary pieces of legislation. ${ }^{54}$ Crete posted a large number of public inscriptions containing the text of enacted laws. ${ }^{55}$ The temple to Apollo Delphinios in the Cretan town of Dreos, a building that dated back to the eighth century BCE and bordered on the town's central gathering place, had several laws inscribed on its eastern wall. ${ }^{56}$ The town of Gortyn inscribed a collection of law, now known as the Gortyn code, on the side of a temple to Apollo. These inscriptions probably dated back to the late sixth century BCE and were carved in letters painted in red ochre ranging from 4 to 25 centimeters (roughly $1 \frac{1}{2}$ to 10 inches) high for readability. ${ }^{57}$ A bronze plaque from the same era was inscribed with land

49. Meryll Dean, Japanese Legal System 55-61 (2d ed. 2002); Jerôme Bourgon \& PierreEmmanuel Roux, The Chosŏn Law Codes in an East Asian Perspective, in The SpIRIT OF KoreAn Law, supra note 48, at 19, 20.

50. DeAn, supra note 49 , at 60 . These written laws were not always made available to the public, though. For example, the Kujikata Osadademegaki of 1742 was a rules manual given only to Tokugawa-era administrators. $I d$. at 58.

51. Paul Heng-Chao Ch'en, The Formation of the Early Meiji Legal Order 3 (Oxford Univ. Press London Oriental Series Vol. 35, 1981). The three codes were the Kari keiritsu (Provisional Criminal Code), Shinritsu kouryou (Essence of the New Code), and Keitei ritsurei (Statutes and Substatutes as Amended).

52. See generally Bourgon \& Roux, supra note 49.

53. GAGARIN, supra note 22, at 1, 39. Gagarin asserts Greece was unusual in this aspect and that many other ancient societies primarily published laws as academic exercises or for propaganda purposes. Id. at 1 .

54. Id. at 43 .

55. Id. Gagarin says Crete did not necessarily publish much more than the other ancient Greek city-states; we may just have more evidence remaining of Cretan publishing. While Crete inscribed many of its laws in stone, other Greek cities supposedly wrote their laws on more fragile materials such as wood or papyrus. Id. at 43-44.

56. Id. at 45-46. Gagarin does not make clear exactly to when the inscriptions date, but in the context of his book, it seems reasonable to infer that they were carved into the wall some time after the temple's construction.

57. Id. at 50, 151-52. 
regulations from a colony of the Locris region and could be hung on a wall for public viewing. .5

\$16 Athenians considered their city-state the greatest of all ancient Greece ${ }^{59}$ and were proud of their body of laws, called nomoi, which had a long history of public access. ${ }^{60}$ Draco, in 621-620 BCE, and Solon, in 594-593 BCE, inscribed their rules on objects called axones and kyrbeis that were posted in public locations. ${ }^{61}$ The city was a prolific legal publisher, inscribing numerous laws on bronze and stone stelae in locales open to the public. In $403 \mathrm{BCE}$, at least 250 of these stelae still survived. ${ }^{62}$ They were spread across Athens, ${ }^{63}$ but each stele would usually be located in a place with a logical connection to the law. For example, the stele with the law on homicide was posted where preliminary homicide hearings were held. ${ }^{64}$

I17 Publication by stelae presented a potential currency problem. If the city enacted a new law, did they always remove all the stelae with replaced or amended laws? To address this, Athens appointed a council of Anagrapheis (Recorders) in 410 BCE to create an official record of laws passed by Solon; by 399 BCE, the Anagrapheis presented their finished work, a list of legislation currently in force. ${ }^{65}$ The texts of newly passed laws were posted on a wall of the Stoa Basileos. ${ }^{66}$

I18 Around this time, the Athenian government set up an official archive at the Metroon, a shrine dedicated to the mother of the gods, which thereafter received a copy of each enacted law. ${ }^{67}$ Old records and speeches imply that laws in the Metroon were organized by broad categories and by date passed, so finding a specific law could have been a daunting task, ${ }^{68}$ although some speeches refer to "public slaves" who oversaw and retrieved records and who might have helped researchers. ${ }^{69}$

I19 All the writing and inscribing in the land does not help if the majority of the public cannot read. The traditional classical studies view held that ancient Greek society had a sufficiently high literacy rate to assume that printed and

58. Id. at 60 .

59. Anthony Everitt, The Rise of Athens: The Story of the World's Greatest Civilization 270-71 (2016); Tom Holland, Persian Fire: The First World Empire and the Battle for the West 100-03, 365-70 (2005); James Sickinger, The Laws of Athens: Publication, Preservation, Consultation, in The LaW and the Courts in Ancient Greece 93 (Edward M. Harris \& Lene Rubinstein eds., 2004). Spartans, of course, would beg to differ.

60. Sickinger, supra note 59, at 93.

61. Id. at 94. Scholars think it likely that axones and kyrbeis are the same type of item: multisided wooden pillars with an axis so the reader could turn them. Axones, in The Oxford Classical DicTIONARY (Simon Hornblower \& Anthony Spawforth eds., 3d ed. rev. 2003). These objects have long since disappeared, so scholars do not know for sure where they were located, but most agree that axones and kyrbeis were posted in public places. GAGARIN, supra note 22, at 181-82.

62. Sickinger, supra note 59 , at 94-95.

63. Id. at 95 .

64. Id. at 95-96. Regardless, some scholars think the scattered distribution would have made it hard to research the relevant law. See, e.g., GAGARIN, supra note 22, at 182.

65. GAGARIN, supra note 22, at 183.

66. Id. at 184. The Stoa Basileos was a sheltered area located on the northwest corner of the Athenian agora; it was originally the headquarters for Athens's archōn basileus, the magistrate in charge of religious matters. Charles W. Hedrick, Jr., Spaces of Government: Civic Architecture and Memory, in A Companion to Ancient Greek Government 385, 395-96 (Hans Beck ed., 2013), Wiley Online Library, doi: 10.1002/9781118303214. But see GAGARIN, supra note 22, at 184 (arguing that only pending legislation was posted on the Stoa Basileos's wall).

67. Sickinger, supra note 59, at 93.

68. Id. at $102-03$.

69. Id. at 104 . 
inscribed laws were intended for the general public's legal knowledge. ${ }^{70}$ Some contemporary scholars, however, argue that most literate people in ancient Greece were from the elite, so the laws inscribed in public places were mostly for propaganda purposes, much like Hammurabi’s Code. ${ }^{71}$ Professor Michael Gagarin counters that the texts were written in clear script, unlike the poetic, elegant script aimed at upper-class readers on Hammurabi's Stele. ${ }^{72}$ Even if ancient Greece's literacy rate was low, Gagarin continues, it was still higher than in other ancient societies. ${ }^{73}$

I20 The text of speeches from the time hinted that jurors were expected to be able to read laws and that litigants in trials cited relevant laws in their disputes. ${ }^{74}$ Athenians were prodigious litigators, to the extent that ordinary citizens, not just an elite class, probably argued in court. ${ }^{75}$ Even if making the text of the law available to all Athenians was not the only goal behind publication, it was probably one of their most important motivations.

I21 As in Babylonia and dynastic China, ancient Greece offered the public an authenticated copy of the law. It later made efforts to preserve that law for the future. Stelae, placards on walls, and centrally archived copies of laws may not have allowed as wide a distribution as China's printed codes, but the ancient Greeks considered access to all the law for all members of the public a noteworthy goalanother step toward the modern ideals embodied in UELMA.

\section{Rome}

I22 Ancient Rome evolved from a kingdom to a republic and then an empire. ${ }^{76}$ As Roman government changed, so did the sources of law that it drew on, as well as the ways the public could access the law. Thankfully for Roman citizens and for modern researchers, not all Roman rulers were as petulant as Caligula.

\section{The Monarchy}

I23 There is little evidence as to whether Rome published any laws during its kingdom era. It is generally accepted today that Rome's kings mostly ruled by custom; the question is how much of this customary law was supplemented by royal

70. Gagarin, supra note 22, at 67; see also William V. Harris, Ancient Literacy 8-9 (1989), ACLS Humanities E-Book, http://hdl.handle.net/2027/heb.01448.0001.001 [https://perma.cc/MJL9 -F7GB].

71. GAgARIN, supra note 22, at 67-68.

72. Id. at $69-70$.

73. Id. Gagarin cites one estimate that ancient Crete had a 5 percent literacy rate, while the fifthcentury BCE Athenian literacy rate was at least 10 percent. Id. at 70, 176-77. Gagarin further notes that by the sixth century BCE, even rural shepherds in Greece were writing short texts. Id. at 177; see also HARRIs, supra note 70, at 1-24 (discussing issues with applying modern definitions of "literacy" to ancient Greece and Rome).

74. Gagarin, supra note 22, at 178-80; Sickinger, supra note 59, at 104.

75. Adriann Lanni, LaW and Order in Ancient Athens 131-32 (2016).

76. Paul du Plessis, Borkowski’s Textbook on Roman Law $\$ \$ 1.1-1.3$ (5th ed. 2015). The Byzantine Empire is part of this continuum. Modern historians in the West usually refer to the Eastern Roman Empire as the Byzantine Empire, but the rulers and citizens of that empire would have considered themselves Romans, their empire a continuation of Rome's. Timothy E. Gregory, A History of Byzantium 1-2 (2005). 
decrees ${ }^{77}$ Pomponius, a legal historian from the second century CE, said that some of the kings passed statutes, called leges regiae, which were based on advice from citizen advisory groups called the curiae. ${ }^{78}$ Some leges were supposedly transcribed on tablets and then later compiled into a book by the pontifex maximus, ${ }^{79}$ Gaius Papirius, so that the public could read them. ${ }^{80}$ Modern scholars question whether the leges regiae really existed, believing that ancient historians made up the leges entirely or backdated laws from later in Roman history. ${ }^{81}$

\section{The Republic}

I24 The early Roman Republic was split by the Conflict of the Orders, a decades-long battle between the plebeians-ordinary Roman citizens who did much of the fighting and labor-and the ruling patrician class, which took the money earned by the plebians' work. ${ }^{82}$ In 494 BCE, the plebeians, frustrated by their lack of power and the economic situation, staged mass walkouts from Rome. The patricians slowly capitulated, and eventually plebeians and patricians had almost equal rights. ${ }^{83}$ One of the plebeians' demands was for Rome's law to be codified and published. ${ }^{84}$ The result was the Twelve Tables, sometimes described as the first code of Roman law. ${ }^{85}$ The Tables were originally inscribed on bronze tablets located in the rostra ${ }^{86}$ for public inspection. ${ }^{87}$ The original tablets are long lost to the ages, but it is likely that copies on less-permanent materials were made. ${ }^{88}$ The Tables' text became well known through Roman society and a founding principle of Western jurisprudence; centuries later, Cicero spoke of children memorizing the Tables as part of their lessons. ${ }^{89}$

I25 The patricians did not make the entire body of Roman law public; the Tables were still, after all, a grudging concession. Other parts of Roman law remained unpublished, especially those that supported patrician power over plebe-

77. DU PLEssis, supra note $76, \S 2.1$.

78. Id. $\$ 2.1 .2$, citing Dig. 1.2.2.1-2 (Pomponius, Enchiridion).

79. The pontifices were one of the four major colleges of priests in early Rome. During the kingdom era, they were responsible for state religious duties such as sacrifices and adoptions, they advised magistrates and citizens on the sacred law, and they recorded their decisions in books. The pontifex maximus was the leader of the college who acted as its spokesman. Pontifex/pontifices, in THE OXFORD Classical Dictionary, supra note 61.

80. DU Plessis, supra note 76, \$2.1.2, citing Dig. 1.2.2.1-2 (Pomponius, Enchiridion); Alan Watson, Roman Private Law and the Leges Regiae, 62 J. Roman Stud. 100, 103-04 (1972).

81. Watson, supra note 80 , at 100 .

82. MARy BeARD, SPQR: A History of Ancient Rome 137, 145 (2015). The Conflict's name comes from ordo, which means "social rank" in Latin. Id.

83. Id. at $146-47$.

84. T.J. Cornell, The Beginnings of Rome: Italy and Rome from the Bronze Age to the Punic WARs (c. 1000-264 BC), at 272 (1995).

85. DU PlEssis, supra note $76, \S 2.2 .1 .1$. As with other ancient compilations of law, though, the Twelve Tables would not be considered a code by modern standards. Id.

86. The speaker's platform in the Comitium, the main place for political assembly in Republican Rome. Rostra, in The Oxford Classical Dictionary, supra note 61; Comitium, id.

87. Du Plessis, supra note 76, at $\$ 2.2 .1 .1$, quoting Dig. 1.2.2.4 (Pomponius, Enchiridion); CoRNELL, supra note 84 , at 278. At least, this is what we assume; scholars believe that the Gauls destroyed the original Tables when they pillaged Rome around 386 BCE. Id. Pomponius said that the tablets were inscribed in ivory, but other sources assert that it was bronze, which seems more plausible. Id. at 278, 453 n. 24.

88. CORNELL, supra note 84 , at 278 .

89. Id. 
ians. ${ }^{90}$ The literacy rate in early Republican Rome may have been lower than 10 percent, so this increased access was still limited to a relatively small percentage of the overall population. ${ }^{91}$ Nevertheless, posting a substantial portion of the law so that it could be seen by more than just the elites was an important statement. Even if the patricians originally created the Tables to appease rebellious plebeians, they successfully made the law known to a wider range of Romans than before.

I26 As Rome's jurisprudence evolved over the centuries, different sources of law rose and fell in importance. Many of these other sources of law were also available for Roman citizens in general to view, at least for a time. Senatorial decrees were sometimes inscribed onto a bronze tablet that had to be displayed for at least 24 days. $^{92}$ When a new praetor ${ }^{93}$ took office, he posted an edict, a set of rules that described how he would carry out his duties, on a wooden board outside his office. $^{94}$

\section{The Empire}

I27 The Roman Empire's rulers differed on the importance of public access to edicts. Caligula certainly did not seem to think such access desirable. Fortunately, several emperors who reigned as power shifted from Rome to Constantinople placed a higher priority on widely publicizing the law. Diocletian (r. 284-305 CE) had his edictum de pretiis rerum venalium (Edict on Maximum Prices) of 301 engraved on marble that scholars assume were posted in public gathering areas. ${ }^{95}$ Archaeologists unearthed fragments of a copy of this edict in the city of Aphrodisias $^{96}$ that was originally in the form of a balustrade ${ }^{97}$ near a public building. ${ }^{98}$ Shards from marble tablets with the same edict were unearthed in Ptolemais; ${ }^{99}$

90. See Alan Watson, The Spirit of Roman Law 38 (1995) (“The Twelve Tables were prepared by patricians as the law they were willing to share with plebeians. . ..”).

91. See HARris, supra note 70, at 151-53.

92. Tommaso Beggio (trans. Laurence Hooper), Epigraphy, in The Oxford Handbook of Roman Law AND Society $\$ 4.2 .1$ (Paul J. Du Plessis et al. eds., 2016). One example of these tablets that still exists today is the senatus consultum de Bacchanalibus, currently exhibited at the Kunsthistoriches Museum in Vienna. Id. A picture of this tablet is available at the museum's website at https://www .khm.at/de/object/8471949afb/ [https://perma.cc/5UCU-SRJ5].

93. The chief magistrate of Rome. Praetor, in The Oxford Classical Dictionary, supra note 61.

94. DU PLESSIS, supra note 76, $\$ 2.2 .2 .3$.

95. Beggio, supra note 92.

96. Modern-day Geyre, Turkey. Aphrodisias, in The Oxford Classical Dictionary, supra note 61.

97. A balustrade is a row of columns topped by a rail. What is a Balustrade?, ARCHITECTURAL Digest (July 31, 2015), http://www.architecturaldigest.com/story/ad-glossary-define-balustrade [http://perma.cc/EK24-LE4S].

98. Kenan T. Erim et al., The Copy of Diocletian's Edict on Maximum Prices from Aphrodisias in Caria, 60 J. Roman Stud. 120, 121 (1970); Kenan T. Erim \& Joyce Reynolds, The Aphrodisias Copy of Diocletian's Edict on Maximum Prices, 63 J. Roman Stud. 99, 99 (1973). Oddly, Architectural Digest's online glossary asserts that the Roman Empire did not use balustrades. What is a Balustrade?, supra note 97 . Whether this is an overgeneralization by the Digest or an inaccurate description by Erim is unclear.

99. Modern-day Tolmeita, Libya. Giacomo Caputo et al., Diocletian's Price-Edict at Ptolemais (Cyrenaica), 45 J. Roman STUd. 106, 106 (1955). 
these may be from tablets that were posted on a building. ${ }^{100}$ Citizen access to the law was important to this emperor. ${ }^{101}$

I28 Efforts under Diocletian's reign to publish the law went beyond public monuments. This era also saw the first officially approved substantial efforts to codify imperial rescripta. ${ }^{102}$ By the third century CE, the imperial archives were split between two locations and contained 100 years' worth of rescripta, organized chronologically, factors that made it difficult for anyone who wished to research them. ${ }^{103}$ The Codex Gregorianus, followed by the Codex Hermogenianus, made rescripta easier for lawyers, jurists, and researchers to use. These publications converted rescripta from awkward scrolls to convenient codex form and arranged them by subject. ${ }^{104}$ Copies of the Codices were likely sent to provincial and court officials for even greater access, and students at Roman law schools would consult them. ${ }^{105}$

I29 By Theodosius II's reign (408-450 CE), however, Roman law was drifting back to chaos. ${ }^{106}$ The Codex Hermogenianus was not updated. ${ }^{107}$ New rescripta were posted at the locations where they were issued, ${ }^{108}$ but they were numerous and unorganized. In court, the party with the most recent rescript in its favor often won, and it was not unheard of for litigants to present forged rescripta to support their case. ${ }^{109}$ Even if a rescript was genuine, many fourth century CE rescripta came with a caveat stating they were valid only as long as they were not contra ius-contrary to already existing law. Judges then had to sort through the mass of imperial laws to determine what that existing law truly was. ${ }^{110}$

100. Id. We do not know exactly where the tablets in Ptolemais or the balustrade in Aphrodisias were posted because both were broken apart after Diocletian's edict was revoked; the pieces were reused for various building projects over the centuries. Id. at 107; Erim \& Reynolds, supra note 98 , at 99.

101. Again, though, the issue of how many citizens could read the edict arises. Aphrodisias and Ptolemais were both in the Eastern Roman Empire, where Greek was the majority language. Language, in The Oxford Dictionary of Byzantium (Alexander P. Kazhdan ed.), Oxford Reference Online, www.oxfordreference.com/view/10.1093/acref/9780195046526.001.0001/acref -9780195046526-e-3001 [https://perma.cc/ME43-Y4TZ]. Latin was still the official imperial governmental language; the edict was inscribed in Latin in both cities' structures. Id.; Caputo et al., supra note 99, at 114; Erim \& Reynolds, supra note 98, at 99. Caputo notes that Greek-speaking traders would likely have had Greek translations of the law in manuscript form. Id. Nevertheless, even if written in an official language not spoken well by the majority, the availability of a copy of the law in public shows some dedication to accessibility.

102. Serena Connolly, Lives Behind the laws: The World of the Codex HermogeniaNUS 41, 141 (2010). Rescripta were emperors' replies to questions and petitions that were one of the most important forms of legislation in the Roman Empire. Du Plessis, supra note 76, § 2.3.2.7.

103. ConNolly, supra note 102, at 39-40.

104. Id. at 40-41. Even though the word Codex in the titles Codex Gregorianus, Codex Hermogenianus, and Codex Justinianus is usually translated to "Code" in English, it refers to the fact that these works were published as a codex-parchment, papyrus, or wood leaves bound together, as opposed to a scroll. Codex, in The Oxford Classical Dictionary, supra note 61.

105. Connolly, supra note 102, at 41; William Turpin, The Purpose of the Roman Law Codes, 104 Zeitschrift der Savigny-Sitftung für Rechtsgeschichte Romanistische Abteilung 620, 626 (1987).

106. John F. Matthews, Laying Down the Law: A Study of the Theodosian Code 19 (2000).

107. Id.

108. Id. at 13 .

109. Jill Harries, Introduction: The Background to the Code, in The Theodosian Code: StudIES IN the Imperial LAW of LAte Antiquity 1, 2 (Jill Harries \& Ian Wood eds., 2d ed. 2010).

110. Turpin, supra note 105 , at 627-28. 
I30 The code Theodosius II authorized, the Codex Theodosianus of 438, largely focused on another form of imperial law, the constitutiones. Constitutiones were legislation aimed at the general public, not responses to specific legal scenarios like the rescripta. The emperor issued constitutiones as edicta, edicts issued to the general public; or as epistulae, letters sent to officials and regional governors. ${ }^{111}$ Constitutiones were read aloud to the public, then posted in public areas using various materials from ethereal paper, linen, or wood to more permanent bronze or stone, ${ }^{112}$ so the text of the laws was available to citizens prior to Theodosius II's reign. The Codex Theodosianus, however, marked the first time constitutiones were collected and organized in one collection. ${ }^{113}$ The Codex became binding law over both the Eastern and Western Roman Empires, and copies were prepared exclusively by officers called constitutionarii; anyone else who published a copy of the Codex could be fined. ${ }^{114}$ The Senate ordered the praetorian prefect ${ }^{115}$ to provide copies of the Codex for the provinces. ${ }^{116}$

$\llbracket 31$ Original copies of the Codex fell into three classes, called corpora. The first corpus was the original copy written by Theodosius's "divine hand," which stayed at the praetorian prefect's office and effectively became the Eastern Roman Empire's official copy. ${ }^{117}$ Two copies were made of Theodosius's original. One copy became a corpus of one, the Western Roman Empire's official copy, kept at the archives of the praefectus urbi. ${ }^{118}$ The other copy became the template for the last corpus, all future copies of the Codex. Theodosius's praetorian prefect, Faustus, took responsibility for delivering a copy from the third corpus to the Empire's African provinces. ${ }^{119}$

I32 The Theodosian government took several steps to ensure that copies of the Codex accurately reproduced the original's text. It authorized only one way to publish the Codex: hand copying by the constitutionarii, with all words written out in full-no abbreviations or other shorthand, such as symbols. ${ }^{120}$ Public archives and praetorian offices across the Empire received a copy, kept there at government expense. ${ }^{121}$ These procedures made authentic (as possible, at any rate) copies easier to obtain, but did not satisfy demand for the new Codex. Even imperial officials resorted to pirated copies to fill their needs, regardless of the official ban. ${ }^{122}$ Theodosius's work, despite the supply issues, represented a major effort by a government to make the law easy to access by its full citizenry. He had an even greater ambition

111. MatThews, supra note 106, at 16-17.

112. Id. at 17 .

113. Id. at 12 .

114. Id. at 31 .

115. In Theodosius's time, the praetorian prefect was a member of the emperor's advisory council who held significant civil and financial administrative duties and who helped create imperial policy. Praefectus praetorio, in The Oxford Classical Dictionary, supra note 61.

116. MatThews, supra note 106, at 42.

117. Id. at 49.

118. Id. The praefectus urbi was the "Prefect of the City of Rome," a magistrate who was the emperor's deputy in that city. In Theodosius's time, this prefect also presided over the Senate and was responsible for public order. Praefectus urbi, in The Oxford Classical Dictionary, supra note 61.

119. MatThews, supra note 106, at 50.

120. Id. at 49,53 .

121. Id. at 53.

122. Id. at 32 . 
to codify a larger body of Roman law in one collection but could not accomplish it; that fell to a later emperor. ${ }^{123}$

\section{The Byzantine Empire and Justinian's Corpus Juris Civilis}

I33 Justinian (527-565 CE) was one of history's most ambitious emperors. Historians talk about his "grand design" for returning the Roman Empire to its former glory. ${ }^{124}$ Today, however, he is best known for the legal compilations he commissioned: the Codex, Digest, Institutes, and Novellae-collectively known as the Corpus Juris Civilis (CJC). ${ }^{125}$ The CJC had many purposes. It was in no small part a project to demonstrate Justinian's power. ${ }^{126}$ The emperor also wished to simplify litigation and clarify imperial law by condensing it to one collection that would be the only source to which lawyers and judges needed to refer. ${ }^{127}$ Justinian also intended the parts of the CJC to become the new textbook for law students ${ }^{128}$ and an incentive for bright young minds to learn Latin in the Greek-dominated Byzantine Empire. ${ }^{129}$

\$34 To achieve these goals, the CJC had to be available to the public. In the constitutio officially promulgating the Digest, Justinian declared that the empire should "make manifest the same system of law to all men" and that "the means of purchasing (the entire collection of law) at a trifling price should be offered both to rich and poor." ${ }^{130}$ Justinian also made it clear that all law students should have a copy of his Digest, Institutes, and Codex; after all, they were the textbooks for his new legal curriculum. ${ }^{131}$ He ordered all judges to apply the new law and Praetorian Prefects to spread the word; ${ }^{132}$ presumably one of the primary methods the prefects

123. Id. at 10-11, 18-19; John Matthews, The Making of the Text, in The Theodosian Code, supra note 109, at 23.

124. Andrew Louth, Justinian and His Legacy, in The Cambridge History of the ByzanTiNe EMPIRE C. 500-1492, at 99, 105-23 (Jonathan Shepard ed., 2008). Justinian's successes on these fronts were short lived. Much long-lasting and noteworthy construction took place under his watch, but by his death, many citizens thought him a tyrant. JOHN W. BARKER, JUSTINIAN AND THE LATER RoMAN EMPIRE 201-03 (1966). He sought to unify the Christian church and eliminate paganism in the Empire, but the church remained divided by theological disputes. Id. at 212-13. Justinian retook much of the Western Roman Empire, but his successors could not hold on to his conquests. Id. at 213-44; Louth, supra, at 123-28.

125. Wolfgang Kaiser, Justinian and the Corpus Iuris Civilis, in The Cambridge Companion To Roman LaW 119, 123 (David Johnston ed., 2015).

126. See, e.g., Const. Deo auctore $\$ 2$, in 1 The Digest of Justinian xiii-xiv (Charles Henry Monro trans., 1904) (describing the massive scope of the project, which "appeared. .." to be impossible, but was completed and published "under our own brilliant name"), and Const. Tanta pr., in 1 Digest OF Justinian, at XXv ("A thing which before our command none ever expected or deemed to be at all possible for human endeavour"). There is also speculation that Justinian hoped to use the Digest to distract his citizens from the recent and bloody Nika Riots. David Pugsley, On Compiling Justinian's Digest: The Victory Riots and the Appendix Mass, 11 Oxford J. Legal Stud. 325, 325-26 (1991). Note that a large portion of the credit for the rapid completion of these books goes to Justinian's quaestor (the emperor's legal advisor and draftsman). See generally TONY HonORÉ, TRIBONIAN (1978).

127. See generally Const. Tanta, supra note 126.

128. See generally Const. Omnem, in 1 Digest of Justinian, supra note 126, at xviii, xviiixxiv.

129. HonOrÉ, supra note 126, at 49. Latin was Justinian's preferred language, although he could also speak and read Greek. Id. at 25; BARKER, supra note 124, at 171-72.

130. Const. Tanta, supra note $126, \$ 12$.

131. Const. Omnem, supra note $128, \$ 7$.

132. Const. Tanta, supra note $126, \S 24$. 
used was distributing copies of the CJC. Justinian also planned to publish a compilation of his Novellae, the new constitutiones Justinian issued after the Codex was published, but he was unable to complete that project in his lifetime. ${ }^{133}$ Creating enough copies of Justinian's new restatement of Roman law must have been a monumental job, but the Byzantine capital of Constantinople had professional scribes up to the task. ${ }^{134}$ Around 75 copies were made and distributed to imperial offices. ${ }^{135}$

I135 Unlike Theodosius, Justinian did not ban anyone outside the government from making copies of his books. Justinian, however, did take similar measures to ensure authenticity and ease of use. All terms and references were to be spelled out; no symbols or abbreviations could be used, as this practice had caused confusion in the past. ${ }^{136} \mathrm{He}$ also forbade anyone from creating commentaries on his books under penalty of forgery, noting that the proliferation of juristic commentaries on the law was a major reason for the previously chaotic state of Roman law. ${ }^{137}$ Such commentaries also had the potential to confuse future copyists, who might mistake the commentary for the original material. ${ }^{138}$ Any copy containing abbreviations or symbols could not be cited as authority in court, and the person who sold the copy could be criminally punished and fined twice the book's sale price. ${ }^{139}$ Anyone who cited to a source besides the Codex, Digest, Institutes, or Novellae could be charged with forgery. ${ }^{140}$

I36 Even if some of Justinian's motivations behind his magnum opus were his own glory and desire to support a dying language, scholars agree that the primary impetus behind the Digest, Codex, and Institutes was to make the law more comprehensible and easier to access to imperial citizens. Original copies of Justinian's works may have been lost to history, but even today, fragments from several generations of copies of the Corpus Juris Civilis are the major source for much of modern scholars' knowledge of Roman law. ${ }^{141}$

\37 The story of Roman legal publishing, as with dynastic China, is one of evolution. Authenticity and availability were issues in the monarchy and the early republic. The laws the government reluctantly handed down were either of dubious

133. Timothy G. Kearley, The Creation and Transmission of Justinian's Novels, 102 LAW LiBR. J. 377, 379-80, 2010 LAW LiBR. J. 22, II 6. Future scholars had to rely on private collections to piece together the Novellae text. Id.

134. E.A. Lowe, Greek Symptoms in a Sixth-Century Manuscript of St. Augustine and in a Group of Latin Legal Manuscripts, in 2 E.A. Lowe, PAlaeographical Papers 1907-1965, at 466, 472 (1972).

135. Olga Tellegen-Couperus, A Short History of Roman LaW $\$ 12.5 .2$ (1993). Unfortunately, none of these original copies exist today; the editions of the Corpus Juris Civilis scholars use today are based on fragments assembled from later copies and translations. Id. $\$ 12.5$; O.F. RoBINsoN, The Sources of Roman Law 57-60 (1997).

136. Const. Tanta, supra note 126, $\$ 22$; Tellegen-Couperus, supra note $135, \S 12.5 .3$.

137. Const. Tanta, supra note 126, $\$ 21$. This rule, however, was more honored in the breach. H.F. Jolowicz \& Barry Nicholas, Historical Introduction to the Study of Roman Law 482 (3d ed. 1972).

138. Tellegen-Couperus, supra note $135, \$ 12.5 .3$.

139. Const. Tanta, supra note $126, \$ 22$.

140. Id. $\$ 19$.

141. DU PLEssis, supra note 76, $\$$ 2.5.3. Ironically, Justinian's project had the side effect of destroying many older Roman law publications, either deliberately or through neglect. JoHN HENRY Merryman \& Rogelio Pérez-Perdomo, The Civil Law Tradition 7 (3d ed. 2007). 
origin or only a partial selection of the full body of laws. As the Republic entered its later years, the government made its laws easier to access and authenticate through posting in public spaces. At the same time, these posted laws were not designed for permanence. The Empire introduced a profusion of laws, increasing theoretical availability to the extent that the law effectively became less available to researchers and harder to authenticate. Theodosius II's and Justinian's compilations brought Roman law's publication journey even closer to the same principles of availability, authentication, and permanence that UELMA is based on today.

\section{England}

I138 Before and shortly after the time of the Norman Conquest, England's government used verbal methods to inform their subjects about the law. Under Edward the Confessor (r. 1042-1066), sheriffs presiding over shiremotes ${ }^{142}$ proclaimed royal edicts to the assembled people. ${ }^{143}$ After William the Conqueror (r. 1066-1087) seized control of the land and shiremotes became county courts, sheriffs still read royal proclamations to the people during court sessions. ${ }^{144}$

I39 Henry I (r. 1100-1135) created his Coronation Charter ${ }^{145}$ with its propaganda value at least partially in mind. ${ }^{146}$ By letting his subjects know the promises he had made, they would see how just a ruler he would be. Henry sent a copy to all shires in England and ordered them to keep it in their most important cathedrals or abbeys. ${ }^{147}$ Publicity for Magna Carta went a step further. Shires had to display copies of the "Great Charter" in their cathedrals and abbeys, and sheriffs were ordered to "publicly read [it] throughout your whole balliwick." ${ }^{48}$ In 1265, sheriffs were required to read out the Charters at least semiannually, ${ }^{149}$ then quarterly by 1300. ${ }^{150}$ As with Hammurabi's Stele, these early exhibitions may have been primarily a demonstration of the king's majesty. After 1300, sheriffs read Magna Carta aloud in English and French, but used only Latin before, which few English people, outside the clergy, spoke. ${ }^{151}$

142. A shiremote was a county assembly in Anglo-Saxon England. Shiremote, in J.M. LeLY, WHARTON'S LAW - LEXICON (7th ed. 1883).

143. William A. Morris, The Office of Sheriff in the Anglo-Saxon Period, 31 Eng. Hist. Rev. 20, 36 (1916).

144. 1 James Fitzjames Stephen, A History of the Criminal Law in England 81 (1883). In his History of English Law, Sir William Holdsworth writes that sheriffs in these early county courts "published" the law, but he refers to Stephen for support. 1 William Holdsworth, A History of ENGLish LAW 8 (7th ed. 1956), citing 1 STEPHEN, supra, at 81. It seems fair to infer that Holdsworth's "publication" refers to the reading aloud of laws, not publication in print.

145. Coronation charters were documents kings issued that made certain guarantees to the church and the barons. Charters of Liberties: Henry I, Stephen, and the 'unknown,' in CHARLes Arnold-Baker, The Companion to British History (2d ed. 2001) (e-book), Credo Reference, http:// search.credoreference.com/content/entry/routcbh/charters_of_liberties_henry_i_stephen_and_the _unknown/0 [https://perma.cc/5ZV9-M7ZG].

146. Id.

147. Faith Thompson, The First Century of Magna Carta: Why It Persisted as a DocuMENT 94 (1925) (available in HeinOnline, World Constitutions Illustrated database).

148. Id.

149. Id.

150. Id., citing 1 Statutes of the Realm 136 (1300).

151. Thompson, supra note 147 , at 95 . Thompson notes that even if most laypeople did not understand the Latin, it would have sounded suitably impressive to them. 
I40 Announcing the law as a spectacle instead of as an informative exercise may have reflected the English government's attitudes toward publicizing the law. English courts in the late medieval era did not believe that legislation had to be formally announced to the public to become effective. Parliament represented the entire body of England, the courts argued, so any of its enactments were presumed to be instantly known by all English citizens. ${ }^{152}$ Regardless, to protect their property, people of the time made sure to stay informed about the state of the law, "learn[ing] its rules as they learned the rules of sword play." ${ }^{53}$ Oral communication became insufficient for leading national figures. The Archbishop of Reading ordered every cathedral and collegiate church to post a copy of Magna Carta in a public place visible to all who entered and to replace each copy with a fresh version every spring. ${ }^{154}$ The government quickly ordered these copies removed from church doors, but later sent sealed copies to government officials and to churches. ${ }^{155}$

I41 The European printing revolution ${ }^{156}$ changed how English statutes were publicized for good. By the late 15th century, people who were granted the office of King's Printer published statutes as they were enacted. ${ }^{157}$ This was an important step, but centuries passed before an official compilation covering multiple years of statutes existed in England. ${ }^{158}$ King's Printers assembled volumes of each year's statutes, ${ }^{159}$ and numerous private individuals assembled and printed statutory compilations, ${ }^{160}$ but each collection had flaws. Several compilations that included older statutes written in Latin or law French left those laws untranslated. Errors found their ways into many compilations, and different collections contained conflicting texts for the same statute. Compilations left out some statutes, and they often failed to use the official sources for the statutory text or to even list the sources they used. ${ }^{161}$

I42 Several proposals were made over the centuries to officially compile, revise, and reprint the statutes-from Lord Keeper Nicholas Bacon (Francis's father) under Elizabeth I in 1577, through the Commonwealth era, to a committee created

152. 2 William Holdsworth, A History of English Law 436 (4th ed. 1936), citing YB 39 Edw. 3, fol. 7a-7b, Pasch (1365-1366) (Eng).

153. 2 HoldswORTH, supra note 152 , at 416.

154. M.T. Clanchy, From Memory to Written Record: England 1066-1307, at 267 (3d ed. 2013).

155. Id.

156. See generally Lotte Hellinga, The Gutenberg Revolutions, in A Companion to the HisTORY OF THE BOOK 207-19 (Simon Eliot \& Jonathan Rose eds., 2007).

157. 4 William S. Holdsworth, A History of English LaW 307-08 (1924), citing 1 StatUTES OF THE REALM (1235-1377), at xxi-xxiii. Royal grants to Cambridge and Oxford Universities also gave them the right to print statutes, a point of contention for people granted the right to be declared King's Printer. Ultimately, it was left to the courts to validate Cambridge's and Oxford's rights to print statutes. 11 William Holdsworth, A History of ENGLish LaW 302 (1938).

158. 1 Statutes of the Realm (1235-1377), at xxv.

159. Report from the Committee for Promulgation of the Statutes, 5th December 1796, in 14 Reports from Committees of the House of Commons 119, 119-20 (1803), HathiTrust, https://hdl .handle.net/2027/uc1.c109355525 [https://perma.cc/58FA-4DKZ]. By the turn of the 19th century, the King's Printer distributed about 1100 copies to Members of Parliament, the Privy Council, and some Officers of State. The King's Printer sold copies of individual laws to private individuals but had not sold copies of the annual compilation outside its usual distribution list for years. Id.

160. 1 Statutes of the Realm (1235-1377), at xxi-xxv.

161. Id. 
in 1666 during Charles II's reign. ${ }^{162}$ None came to fruition, and a 1796 House of Commons committee noted in a report that "THERE IS NO AUTHENTIC AND ENTIRE PUBLICATION OF THE STATUTES" 163 and that a substantial number of officially enacted statutes were never published. ${ }^{164}$ At the same time, prominent Enlightenment philosophers such as John Locke and Jeremy Bentham declared that liberty was impossible if the public could not access the laws ruling it. ${ }^{165}$ An 1800 Select Committee investigating the state of British public records declared that "it is clear that many of our Public Statutes . . . were unknown to the most learned Men of Former Times" 166 and repeated the call to publish "a complete and authoritative Edition of all the statutes"167-this time, with results.

I43 The government published Statutes of the Realm, a nine-volume set that collected British statutes from 1235 to 1713 as well as several of the major coronation charters and Magna Carta. ${ }^{168}$ Statutes originally written in Latin or in law French were printed in double columns alongside an English translation. ${ }^{169}$ Statutes of the Realm was a major improvement over its privately issued predecessors, but it still had flaws. The Record Commissioners who created the collection did not always use the best evidence of the statutory text, favoring printed records over manuscript. ${ }^{170}$ The collection contained statutes only through the end of Queen Anne's reign (1707-1714). ${ }^{171}$ It included both statutes still in force and those no longer effective without indicating which was which. ${ }^{172}$ Additionally, the set was expensive and printed in an awkward size, ${ }^{173}$ the appropriately named "elephant folio."174

I44 A major cleanup of English statutes led to the next important step in publication. The Statute Law Revision Acts of 1856, 1861, and 1863 repealed over 1000 obsolete laws from the English books ${ }^{175}$ and paved the way for the Revised Statutes,

162. Report from the Committee upon Temporary Laws, Expired or Expiring, 12th May 1796, in 14 REPORTS FROM COMMITTEES, supra note 159, at 34, 36.

163. Id. at 34 (emphasis in original).

164. Id.

165. Amicus brief of Sixty-Six Library Ass'ns et al. at 15-16, Am. Soc'y for Testing \& Materials v. Public.Resource.Org, Nos. 17-7035, 17-7039 (D.C. Cir. Sept. 25, 2017), https://www.public knowledge.org/assets/uploads/documents/brief-pubres-cadc-2.pdf [https://perma.cc/UDR3-KPCK], citing John Locke, Two Treatises of GovernMENT $\$ 137$ (5th ed. 1728), https://catalog.hathitrust.org /Record/009027013 [https://perma.cc/5Q7L-J2QL], and 3 WORKS OF JEREMY BENTHAM 205 (John Bowring ed., 1843), https://catalog.hathitrust.org/Record/001383956 [https://perma.cc/CPU6-TN9U].

166. First Report, in Reports from the Select Committee, Appointed to Inquire into the State of the Public Records of the Kingdom, \&C 3, 19 (July 4, 1800) (available in Gale Eighteenth Century Collections Online database).

167. Id. at 16 .

168. 1 Courtenay Ilbert, Legislative Methods and Forms 21-22 (1901); 1 Statutes of THE REALM (1235-1377), at Xxix.

169. ILBERT, supra note 168, at 21-22.

170. 11 Holdsworth, supra note 157, at 311. Manuscript refers to handwritten copies. JoHN CARTER, ABC FOR BOOK ColleCtors 147-48 (8th ed. 2004).

171. 11 HolDsworTH, supra note 157, at 311.

172. Id. at 313 .

173. Percy H. Winfield, The Chief Sources of English Legal History 97 (1925).

174. The "elephant folio" was up to 23 inches tall. Book Review (H.G. Richardson \& G.O. Sayles, The English Parliament in the Middle Ages), 67 A.B.A. J. 1654, 1658 (1981); Elephants and Other Folios, Univ. of Wis. River FaLls, https://www.uwrf.edu/AreaResearchCenter/ArchivesRe sources/ElephantsFolios.cfm [https://perma.cc/9HE6-6D43].

175. 11 HOLDSWORTH, supra note 157, at 313-15. 
a compilation of English laws currently in force. ${ }^{176}$ The first edition of the Revised Statutes, released from 1870 to 1878 , freed up considerable shelf space by replacing 118 volumes with $18 .{ }^{177}$ The second edition, which began publication in $1888,{ }^{178}$ further reduced the volume count to 16 and was more affordable. ${ }^{179}$ The Revised Statutes also came in an easier-to-handle format: the first edition in quarto format, the second edition in octavo. ${ }^{180}$

I45 Two more editions of the Revised Statutes came out in 1929 and 1950. ${ }^{181}$ The English government then replaced the Revised Statutes with a loose-booklet publication called Statutes in Force. ${ }^{182}$ The new format was supposed to make updating easier, but the Statutes in Force were still badly out of date by the 1990s. ${ }^{183}$ To give the public easy access to current laws, the U.K. National Archives now publishes English legislation online. ${ }^{184}$ This website provides the full text of the statutes, both in their originally enacted form and with any revisions, from 1988 onward, as well as all statutes from 1297 that were still in force by $1991{ }^{185}$ As of 2017, however, only about half of the revised legislation on the site is completely up to date. ${ }^{186}$ The rest of the revised laws are updated only to 2002, although the Archives plan to complete the work in the future. ${ }^{187}$ In addition, the Archives do not currently authenticate the statutes on their site, noting that they "may need to address authenticity" in the future. ${ }^{188}$

I46 In the days after the Norman Conquest, legal publication may have been more a public relations tactic than an effort to keep the public informed, but at least the governed had some chance to know the content of the laws that ruled them. Announcing new edicts aloud made authenticated law available to even illiterate citizens but restricted that availability to people who could attend court. In addition, verbal dissemination of the law did not leave a permanent version future researchers could access. The advent of printing presses in England raised the

176. 1 IlbBerT, supra note 168 , at 24 .

177. Id. at 25 .

178. Id. at 70 .

179. Id. at 24-25.

180. Winfield, supra note 173, at 95. Quarto format is 9.5 by 12 inches, octavo is 6 by 9 inches. Guide to Book Formats, AвEBooks, https://www.abebooks.com/books/rarebooks/collecting -guide/understanding-rare-books/guide-book-formats.shtml [https://perma.cc/C5P7-6DU5].

181. S.H. Bailey et Al., Smith, Bailey \& Gunn on The Modern English Legal System $\$ 5-022$ (5th ed. 2007).

182. Id.

183. Id. $\$ 5-022$ n.258; Michael Zander, The Law-Making Process $\$ 2.14$ (7th ed. 2015).

184. LegisLATION.GOv.UK, http://www.legislation.gov.uk/ (last visited Mar. 11, 2019).

185. United Kingdom of Great Britain and Northern Ireland-Compilations or Official Codifications, Foreign LAW GuIDE (Marci Hoffman ed.), http://dx.doi.org/10.1163/2213-2996_flg _COM_196402 [https://perma.cc/QJV9-TCNB]. The Archives' website is a great development but may not suit all researchers' needs; updates to revised laws, for example, are slower than with commercial databases, so many lawyers, law libraries, and judges' chambers still find it necessary to pay for database subscriptions. ZANDER, supra note 183, \$2.14; Hester Swift \& Sarah Carter, UPDATE: A Guide to the UK Legal System, GLOBALEx, $\$ 3.1 .3$, http://www.nyulawglobal.org/globalex/United _Kingdom1.html [https://perma.cc/RW4W-V894].

186. Help, Legislation.gov.uK, http://www.legislation.gov.uk/help [https://perma.cc/R32U $-9 \mathrm{XKK}]$.

187. Id.

188. Judith Pratt, Legislation.gov.uk, VoxPoP (Aug. 15, 2010), https://blog.law.cornell.edu /voxpop/2010/08/15/legislationgovuk/ [https:/perma.cc/SQY7-LY68]. 
potential for easier dissemination and permanent access to the laws. It took many centuries and missteps before England implemented a system that provided wide public access to authenticated statutes, even though the government had recognized the need early on. From the eighteenth century onward, England made substantial strides toward the ideals of authenticated laws available to the public at large, as idealized by UEMLA-although that country still has some steps to take to fully realize those ideals.

\section{Virginia}

I47 Citizens of the British Empire's American colonies faced similar periods of highs and lows when it came to ease of access to statutes. Virginia, highly influential and largest of the British North American colonies, ${ }^{189}$ provides a good example. In Virginia's first years, similar to early England, two manuscript copies of laws were sent to each court in the colony and read aloud by commissioners at the beginning of monthly court sessions. ${ }^{190}$ This soon became hard to manage and difficult to research. Counties had to obtain these copies at their own expense, adding a substantial cost to their annual budgets. ${ }^{191}$ In 1699, the House of Burgesses declared that Virginia's laws "do lye in great disorder and confusion" 192 and authorized the creation of a revised code of statutes, which was completed in $1705 .{ }^{193}$ Virginia forbade printing presses through the end of the 17th century, so its laws remained primarily in manuscript form. ${ }^{194}$ Two private London printers issued codes, but one was poorly distributed ${ }^{195}$ and the other so riddled with errors that it was of little use. ${ }^{196}$ By the middle of the 18th century, Virginia finally had enough local presses for printed statutes to supplant manuscripts. ${ }^{197}$ The officially authorized, privately published Parks Edition of 1733 was distributed for free to the governor, burgesses, and justices of the peace across the colony. ${ }^{198}$

I48 The Virginia assembly initiated a revision of the commonwealth's laws in $1776^{199}$ that provided a side benefit in 1783-a new official collection of Virginia

189. W. Hamilton Bryson, Law Books in the Libraries of Colonial Virginians, in "EsTEEMED Bookes of Lawe" and the Legal Culture of Early Virginia 27, 29 (Warren M. Billings \& Brent Tarter eds., 2017).

190. Act LXI of September 1632, in 1 HeNing, supra note 1, at 202; William E. Ross, History of Virginia Codification, 11 VA. L. REg. 79, 80 (1905).

191. 2 Philip Alexander Bruce, Institutional History of Virginia in the Seventeenth Century 513-14 (1964).

192. Act Vili of April 1699, in 3 William Waller Hening, The Statutes at Large: Being a Collection of All the LaWs of Virginia 181 (photo. reprt. 1969) (1823).

193. 3 Hening, supra note 192, at 229 n.; Ross, supra note 190, at 88.

194. George Lewis Chumbley, Colonial Justice in Virginia 146-47 (1997).

195. 2 William Waller Hening, The Statutes at large: Being a Collection of All the LAWS OF VIRGINIA 41 et seq. (photo. reprt. 1969) (1823); Ross, supra note 190, at 84-86.

196. Ross, supra note 190 , at 86 .

197. Chumbley, supra note 194, at 146-47.

198. Ch. XVII of Aug. 1734, $\$$ III, in 4 William Waller Hening, The Statutes at Large: Being a Collection of All the Laws of Virginia 436, 437 (photo. reprt. 1969) (1820); Ross, supra note 190 , at $88-89$.

199. Ch. 9 of Oct. 1776, in 9 William Waller Hening, The Statutes at Large: Being a ColLeCtion of All the Laws of Virginia 175, 175-77 \& n. (photo. reprt. 1969) (1821). The committee the assembly appointed to revise the laws contained some of the country's greatest legal minds of the time: Thomas Jefferson, George Wythe, Edmund Pendleton, George Mason, and Thomas Ludwell Lee. Only 
statutes going back to 1769 , now known as the Chancellors' Revisal. ${ }^{200}$ The government hired Nicolson \& Prentis to print enough copies to satisfy the needs of the Virginia legislature, executive branch, and courts. ${ }^{201}$ Even after the Chancellors' Revisal, though, Virginia's statutes were still spread across numerous books, some of which by the assembly's admission were obtainable only "with difficulty, and only at high prices," and statutes in force were indistinguishable from expired or repealed acts. ${ }^{202}$ The assembly addressed this with the official Revised Code of $1792 .{ }^{203}$ It commissioned Augustine Davis to print this new code and ordered copies for the executive department, clerks and members of the assembly, and all judges and court clerks in the commonwealth. ${ }^{204}$

I49 One of Virginia's most famous sons, Thomas Jefferson, played an important part in the next major development in the commonwealth's legal publishing history. Many of Virginia's earliest laws still existed only in manuscript form, with few if any copies surviving. Local officials often threw away their copies of session laws after a few months. ${ }^{205}$ Anyone who wanted a complete collection of enacted Virginia laws had to buy several different revisions, and even then the collection would miss a large number. ${ }^{206}$ Thomas Jefferson lamented to his mentor George Wythe that much of Virginia's legal history was in danger of vanishing:

Our experience has proved to us that a single copy, or a few, deposited in MS. in the public offices, cannot be relied on for any great length of time. The ravages of fire and of ferocious enemies have had but too much part in producing the very loss we now deplore. How many of the precious works of antiquity were lost, while they existed only in manuscript? ${ }^{207}$

Jefferson, Wythe, and Pendleton presented the committee's work to the assembly in 1779, as Lee died in 1778 and Mason had resigned from it. $I d$. The revisal itself was only partially successful; roughly one-third of the committee's proposals actually became law. Revisal of the Laws 1776-1786 (editorial note), in 2 The Papers of Thomas Jefferson 305, 307 (Julian F. Boyd ed., 1950).

200. 2 Papers of Thomas Jefferson, supra note 199, at 321; Journal of the House of Delegates of the Commonwealth of Virginia May 1783, at 53, 58 (1828), Google Books, https:// books.google.com/books?id=QcGTdl0n0YEC\&num $=14 \& \mathrm{hl}=$ en $\quad[\mathrm{https}: / /$ perma.cc/V85G-EV7B]; Revisal of the Laws 1776-1786, supra note 199, at 321. Presumably this name attached because the assembly required it to be revised and examined by two Court of Chancery judges before it could be printed. Journal of the House of Delegates, supra, at 53.

201. Revisal of the Laws 1776-1786, supra note 199, at 321; Journal of the House OF DeLegates, supra note 200, at 53; 3 Journals of the Council of the State of Virginia Dec. 1, 1781-Nov. 29, 1786, at 359 (Wilmer L. Hall ed., 1952).

202. Revisal of the Laws 1776-1786, supra note 199, at 324, quoting Ch. 9 of Oct. 1789, in 13 William Waller Hening, The Statutes at Large: Being a Collection of All the Laws of Virginia 8, 8-9 (photo. reprt. 1969) (1823).

203. Revisal of the Laws 1776-1786, supra note 199, at 324; Ch. 28 of Dec. 28, 1792, in 13 HENING, supra note 202, at 531-34.

204. Revisal of the Laws 1776-1786, supra note 199, at 324; Ch. 28 of Dec. 28, 1792, supra note $203, \S 4$.

205. St. George Tucker, Note F. of the Lex Scripta, or Written Law, of Virginia, in 1 ST. George Tucker \& Sir William Blackstone, Blackstone's Commentaries: With Notes of Reference to the Constitution and Laws of the Federal Government of the United States; and of the Commonwealth of Virginia (a.k.a. Tucker's Blackstone) app. at 440, 442 (photo. reprt. 1996) (1803).

206. Letter from Thomas Jefferson to George Wythe of Jan. 16, 1796, in 28 THE PAPERS OF Thomas JefFerson 583, 584 (John Catanzariti ed., 2000).

207. Id. at 583-84. Jefferson was prescient here. During the Civil War, many county records from across eastern Virginia were moved to Richmond for safekeeping; ironically, those records were destroyed by a fire on April 3, 1865. As a result, many Virginia court records and other county records from before the Civil War are gone. See Nelson Lankford, Richmond Burning: The Last 
I50 Jefferson proposed a printed compilation of all available Virginia laws, with copies sent to all public libraries in the United States, major European public libraries, and "principal public offices" in Virginia. ${ }^{208}$ Another avid collector of Virginia legal history, lawyer and treatise author William Waller Hening, brought part of Jefferson's vision to fruition. ${ }^{209} \mathrm{He}$ used his and Jefferson's collections of legislation to create as comprehensive as possible a compilation of statutes covering Virginia's early colonial days through $1792 .^{210}$

I51 Hening's work, the Statutes at Large, received state government approval in $1807 .{ }^{211}$ It was published over 12 volumes from 1809 to $1823,{ }^{212}$ and the assembly ordered 800 copies. $^{213}$ Printer Samuel Shepherd published an officially sanctioned collection of Virginia session laws covering 1792 through 1806, of which the assembly ordered 300 copies. ${ }^{214}$ Historical preservation may have driven Hening's project, but it and Shepherd's follow-up were important stages in giving the Virginia public complete and easy access to the text of their commonwealth's legislation.

Days of the Confederate Capital 138-39 (2002); Philip M. Hamer, The Records of Southern History, 5 J. S. Hist. 3, 6 (1939); Research Notes No. 30, Lost Records Localities: Counties and Cities with Missing Records, LIBRARY OF VA., https://www.lva.virginia.gov/public/guides/rn30_lostrecords.pdf [https:// perma.cc/M562-6R6N].

208. Letter from Thomas Jefferson to George Wythe of Jan. 16, 1796, supra note 206, at 584. Jefferson's idea of permanence through numerosity could be thought of as an 18th century precedent to programs such as the Federal Depository Library Program, infra text accompanying note 267, and LOCKSS (Lots of Copies Keep Stuff Safe), a program started by Stanford University in which multiple libraries maintain authenticated electronic copies of materials in a "LOCKSS Box," which is opened to users should the original source of the material become unavailable. This way, LOCKSS ensures access to authentic copies. See What Is LOCKSS?, Lots of CopIes KeEP STUFf SAFE, https://www.lockss.org /about/what-is-lockss/ [https://perma.cc/HX97-353U].

209. William H. Martin, Hening and the Statutes at Large, 13 VA. L. Reg. (n.s.) 25, 25 (1927).

210. Letter from William Waller Hening to Thomas Jefferson, Dec. 26, 1806, Saratoga Rangers, LIBRARY OF CONGRESs, http://hdl.loc.gov/loc.mss/mtj.mtjbib016715 (last visited April 16, 2019); Letter from Thomas Jefferson to William Waller Hening, Jan. 14, 1807, LibRARY OF CONGRESS, http://hdl .loc.gov/loc.mss/mtj.mtjbib016813 [https://perma.cc/HS39-B4T7]; Martin, supra note 209, at 30-33. While Jefferson must have been pleased that someone had realized his dream of numerous printed copies of the commonwealth's early laws, Hening did fall short in one aspect. Jefferson implored Hening to "take measures for having the typography \& paper worthy of the work," stating that the quality of the printing done for some earlier codifications were "unworthy of the history of Tom Thumb." Letter from Thomas Jefferson to William Waller Hening, Jan. 14, 1807. Regrettably, Hening's choice of printers used highly acidic paper that has not stood the test of time. William J. Van Schreeven, Prefatory Note to the Facsimile Reprint, in 1 HenING, supra note 1, at [xxvi]. Fortunately, Hening's work survived long enough for the University Press of Virginia to publish a new facsimile run in 1969.

211. Act of Feb. 5, 1808, ch. 27, 1807 Va. Acts 24; William Waller Hening, Preface to the First Edition, in 1 HeNING, supra note 1, at xi.

212. Martin, supra note 209, at 30-33. A second edition of the first four volumes of Hening's Statutes at Large was published from 1820-1823. Id. at 33.

213. Act of Feb. 5, 1808, ch. 27, 1807 Va. Acts 24; Act of Mar. 10, 1819, ch. 18, 1818 Va. Acts 15; Act of Jan. 23, 1823, ch. 12, 1822 Va. Acts 15. The General Assembly also authorized the executive branch to sell 500 copies of Hening's publication to fund a library for the use of the Court of Appeals, General Court, and General Assembly. Ch. 12, \$1.

214. Act of Mar. 10, 1835, ch. 15, 1834-35 Va. Acts 16. In the 20th century, the Virginia State Law Library published Waverly K. Winfree \& Randolph W. Church, The LaWs of Virginia, Being a Supplement to Hening's the Statutes at Large (1971), to fill in earlier gaps in Hening's publication using copies recovered from the British Public Record Office. Alexis Fetzer Sharp \& Kathleen Klepfer, Statutory Law, in A Guide to Legal Research in Virginia II 3.302 (Joyce Manna Janto ed., 8th ed. 2017). 
\52 Hening's and Shepherd's works, however, still did not solve the puzzle of providing organized and current access to the law. Both men's collections were organized chronologically, with expired and repealed laws aside those still in force. The Code of 1819 was the first compilation of Virginia statutes to organize the laws currently in force by subject, ${ }^{215}$ and it led a series of official and unofficial efforts to codify Virginia statutes throughout the nineteenth century. ${ }^{216}$ Although these new codes organized the law much better, currency was still a problem-a decade or more could pass before a new supplement arrived, meaning that researchers had to go back and forth between the last code and supplement along with several volumes of session laws to determine the current state of the law. ${ }^{217}$

I53 Richmond attorney (and future attorney general of Virginia) John Garland Pollard was responsible for the Code of 1904, which addressed the currency issue by introducing regular biennial updates, in keeping with the assembly's schedule at that time. ${ }^{218}$ The assembly officially approved the Code of 1904 but did not authorize any funds to print it. ${ }^{219}$ It ordered a new revision, the Code of 1919, to renovate a subject framework stretched beyond its breaking point by a flood of new laws. ${ }^{220}$ In a slightly odd move, the assembly had this code printed in an unannotated edition and an annotated version. ${ }^{221}$ One copy of the annotated code went to legislative, executive, and state and federal judicial officers, five copies to the state librarian and law librarian, and two copies to the Supreme Court of Appeals libraries in Wytheville and Staunton. ${ }^{22}$ State-owned educational institutions, private educational institutions in Virginia with a library, and state charitable institutions each received one copy of the unannotated code. ${ }^{223}$

I54 The Code of 1919 was a much-needed refresh, but it also quickly became outdated, ${ }^{224}$ and Pollard's biennial supplements were by now poorly organized. ${ }^{225}$ A private publisher, the Michie Company, stepped into the breach with The Code of Virginia as Amended to Adjournment of General Assembly 1924, a biennially updated publication that soon became known as the Michie Code. ${ }^{226}$ The assembly acknowledged the need for another official revision of a code that had become "so difficult (to research) as to baffle the attorney, much less the layman." 227 A new

215. Kent Olson, State Codes, in Virginia LaW Books: Essays and Bibliographies 1, 19-20 (W. Hamilton Bryson ed., 2000).

216. See id. at 12-29 for an annotated list of the codifications of Virginia law from the commonwealth's beginning through the present day.

217. $I d$. at 4 .

218. Id. at 4,23 .

219. Act of Dec. 18, 1903, ch. 471, 1902-3-4 Extra Session Va. Acts 733. The Code of 1904 was also noteworthy as the only time West Publishing was involved in publishing Virginia statutes in the 20th century. Id. West did not publish Virginia statutes again until it released West's Annotated Code of Virginia in 2001. Kent Olson, Alyssa Altshuler \& Gail Zwirner, West's New Annotated Code of Virginia, VA. LAw., Apr. 2002, at 44.

220. Act of Mar. 21, 1914, ch. 193, 1914 Va. Acts 300.

221. Olson, supra note 215, at 25.

222. Act of Mar. 8, 1918, ch. 108, \$6, 1918 Va. Acts 211-12.

223. $I d$.

224. Olson, supra note 215 , at 26.

225. Id. at $25-26$.

226. Id. at $26-28$.

227. Recodification of the Code of Virginia: Report of the Virginia Advisory Legislative Council to the Governor and the General Assembly of Virginia, H. 1946-19, at 2-3, 6. 
commission supervised this revision ${ }^{228}$ and hired Michie to publish the new Code of 1950,229 the version of Virginia's statutory code still in force today.

I55 It is unclear how many copies of the new Code of 1950 the government provided to its officers and to libraries, although a couple of its sections provide hints. Section 9-77 stated that the commission "may arrange" for Virginia's government to distribute copies of the code in the same manner as the session laws. ${ }^{230}$ Section 2-232 sets out the distribution list for those session laws, which includes assembly members and clerks, the governor and executive officers, judges and clerks, public libraries, K-12 libraries, the state library and law library, and all postsecondary education libraries in Virginia. ${ }^{231}$

I56 The assembly recognized that timely updates were important. Each volume of the Code of 1950 is updated with a pocket part at the end of every legislative session. ${ }^{232}$ The commonwealth also made the committee that created the new code permanent and placed it in charge of future revisions. ${ }^{233}$ Rather than wait to revise the entire code as before, the committee now revises individual titles as needed. ${ }^{234}$ LexisNexis, current owner of the former Michie Company, ${ }^{235}$ still publishes the official code. ${ }^{236}$

I57 While Virginia's law clearly sets out who is responsible for revising and publishing the law, it is vague about making copies of the code available to the public. The commonwealth's Code Commission is in charge of arranging publication, ${ }^{237}$ but no law mandates how many, if any, copies of the code must be distributed to state offices or most libraries. Even former section 9-77's suggestion that the Commission could use the Acts of Assembly's distribution list has been removed.

I58 Instead, a smattering of provisions in title 30 of the Code of Virginia mandate distribution to specific people or organizations, such as law school libraries ${ }^{238}$ or state senators. ${ }^{239}$ The commission still provides gratis copies of the Code of Virginia to some institutions, including the author's. Such distribution of complimentary copies, however, appears to be mostly at the commission's discretion and not compelled by law. The commonwealth must make the Code of Virginia available online to state agencies. ${ }^{240}$ The commission currently makes the online code avail-

228. Act of Mar. 30, 1946, ch. 400, 1946 Va. Acts 970.

229. Report of the Commission on Code Recodification, reproduced in 1 VA. CodE ANN. ix, $\mathrm{x}-$ xi (1949). The assembly approved the code in 1948, but it became effective on February 1, 1950, hence the name. Preface, in 1 VA. Code Ann. iii (1949); VA. Code Ann. \$1-2 (2014).

230. VA. Code Ann. \$ 9-77 (1949).

231. Id. \$2-232.

232. Olson, supra note 215 , at 29.

233. Act of Mar. 16, 1948, ch. 262, 1948 Va. Laws 496.

234. VA. Code AnN. \$30-152 (2015).

235. See David W. Parrish, Jr., The Michie Company, in Virginia Law Books, supra note 215, at 557-61, for the story of how Michie was absorbed into different companies that eventually became part of Reed Elsevier (now known as RELX Group).

236. See Code of Virginia, VA. LegisLative Info. Sys., https://law.lis.virginia.gov/vacode [https://perma.cc/PK69-LPQA] ("The Code of Virginia online database excludes material copyrighted by the publisher, Michie, a division of Matthew Bender.").

237. VA. Code Ann. \$30-146 (2015).

238. VA. Code Ann. $\$ 30-34.8$ (Supp. 2017). Specifically, one copy must be provided from the Code Commission's surplus stock to law school libraries that do not already have one.

239. VA. Code Ann. $\$ 30-15.2$ (2015). The Virginia Senate pays for these copies. There does not seem to be an equivalent provision for providing state delegates with a copy.

240. VA. CODE ANN. $\$ \$ 30-34.10: 1,30-34.10: 2$ (2015). 
able to the public for free, ${ }^{241}$ but it has to do so only "as resources permit" 242 and may charge reasonable and proportionate access fees. ${ }^{243}$ The commonwealth does not currently authenticate the statutes available on its website, ${ }^{244}$ although it has considered the issue in the past. ${ }^{245}$

I59 Virginia has followed a journey similar to England's in publicizing the law. The commonwealth moved from verbal announcements and poorly maintained collections of session laws to more permanent compilations of statutes organized by subject, demonstrating an interest in giving the public practical access to the law. Virginia's official online system may not currently grant public access to authenticated statutes, and the commonwealth has not enacted UELMA as of $2019,{ }^{246}$ but it has substantially considered the issue and at least expressed the desire to meet the public's need to research the law for which UELMA was designed.

\section{Modern Foreign and International Views}

I60 Civil law jurisdictions have long considered publication an intrinsic element of a law's validity. ${ }^{247}$ The Code Napoleon said that French laws became valid "from the moment at which their promulgation can have been known." 248 Laws did not take effect in areas further away from the capital until people living there reasonably had had time to learn about them; an extra day was added for every 100 kilometers a town was located away from the capital. ${ }^{249}$

I61 Although common law jurisdictions traditionally believed that publication was not critical to a law's authority, ${ }^{250}$ today they recognize its importance. The divide with their civil law counterparts can still be seen, however, by the way they phrase their mandates. The present-day French Civil Code changed its predecessor's requirement and now states that laws take effect the day after publication. ${ }^{251}$ The Basic Law of Germany provides that statutes, unless otherwise specified, take effect 14 days after publication. ${ }^{252}$ South Africa's constitution states that passed

241. Code of Virginia, Сомmonwealth of VA., http://law.lis.virginia.gov/vacode [https:// perma.cc/ZY76-UQRX].

242. VA. CODE ANN. \$30-34.10:1 (2015).

243. Id. $\$ 30-34.10: 3$.

244. See https://law.lis.virginia.gov/vacode [https://perma.cc/M6MT-DRD6].

245. Timothy L. Coggins, Virginia Law: It's Online, But Should You Use It?, VA. Law., June/ July 2008, at 35, 36, http://www.vsb.org/docs/valawyermagazine/vl0708_valaw-online.pdf [https:// perma.cc/CAE2-MEX7].

246. Electronic Legal Material Act, UnIf. LAW Comm'n, https://www.uniformlaws.org /committees/community-home?CommunityKey=02061119-7070-4806-8841-d36afc18ff21 [https:// perma.cc/CR33-FERP].

247. Roland Gray, The Nature and Sources of the LaW 163 (2d ed. 1921).

248. The Code Napoleon; or, The French Civil Code prelim. tit., art. I. ("A Barrister of the Inner Temple" trans., 1841) (available in HeinOnline, World Constitutions Illustrated database).

249. Id. The translation uses the phrase "ten myriameters"; a myriameter equals 10,000 meters. Myria-, Oxford English Dictionary (2d ed. 1989). The author includes this information mainly because he believes the word myriameter is criminally underused today.

250. See supra text accompanying note 152.

251. Code Civil [C. Civ.] [Civil Code] prelim. tit., art. I, translation at Legifrance, https:// www.legifrance.gouv.fr/Traductions/en-English/Legifrance-translations [https://perma.cc/B8A3 -HVJS] (Fr.).

252. Grundgesetz [GG] [BAsic Law], art. 82, translation at Gesetze im Internet, https:// www.gesetze-im-internet.de/englisch_gg/ [https://perma.cc/C4X3-BQRH] (Ger.). 
legislation "must be published promptly, and takes effect when published" unless the enacted law itself states otherwise. ${ }^{253}$ Chile's constitution requires a law to be published within 5 days of its promulgation. ${ }^{254}$ Spain's constitutional requirement is worded more vaguely but still implies urgency: once parliament passes a law, the head of state must order its promulgation and "immediate" publication within 15 days. ${ }^{25}$ The Russian Federation's constitution declares that unpublished laws do not have any force and specifies that "[a]ny normative legal acts concerning human and civil rights, freedoms and obligations shall not have force unless they have been officially published for the information of the general public." 256 Some commentators believe that the Russian constitution's strong requirement is at least partially a reaction to the Soviet Union's tendency to enact secret laws that infringed on its citizens' rights. ${ }^{257}$ Australia's Legislation Act 2003 requires its federal government to maintain a register of enacted legislation ${ }^{258}$ on a website that is open to the public, ${ }^{259}$ although its requirement that parliament place all acts on this register call for this to be done "as soon as practicable after the Act is assented to."260

I62 International bodies also emphasize how important it is for the public to have access to the law. The Universal Declaration of Human Rights states that everyone has the right to receive information. ${ }^{261}$ The Hague Conference on Private International Law and the European Commission held a joint conference in 2012 that recommended, among other things, that all nations make up-to-date and authoritative legislation available online for free, as well as historical laws. ${ }^{262}$

\section{The U.S. Federal Government}

I63 Many people over the years have said that "the United States is a nation of laws." ${ }^{63}$ Can a nation of laws exist if its citizens do not know what those laws are?

253. S. Afr. Const., 1996, $\$ 81$.

254. Constitución Política de la República de Chile [C.P.] art. 75, translation at Chile, World Constitutions Illustrated (Jefri Jay Ruchti ed., Anna I. Velvé Torras et al. trans.) (available in HeinOnline, World Constitutions Illustrated database).

255. Constitución Española [C.E.], art. 56, para. 1; art. 91 (Spain), translation at AgenCia Estatal Boletín Oficial del Estad, http://boe.es/legislacion/constitucion.php [https://perma .cc/8LXK-NG7L].

256. Konstitutsiia Rossisskoi Federatsis [Konst. RF] [Constitution] art. 15(3) (Russ.), translation at The Constitution of the Russian Federation (available in HeinOnline, World Constitutions Illustrated database).

257. William Burnham et al., Law and Legal System of the Russian Federation 665 (5th ed. 2012), citing V.V. Lazarev, Commentary on the Constitution of the Russian Federation (2003); see also W.E. ButLer, Soviet LAW 57-59 (2d ed. 1988) (discussing laws not made available to officials or members of the public affected by them and the impact of this practice).

258. Legislation Act 2003 (Cth) ch 2 pt 1 div 2 s 15A (Austl.), https://www.legislation.gov.au /Details/C2017C00176 [https://perma.cc/VT7C-XNDB] (updated through Act No. 55, 2017).

259. Id. at ch 2 pt 1 div $2 \mathrm{~s} 15 \mathrm{C}$.

260. Id. at ch 2 pt 1 div 3 s 15F.

261. G.A. Res. 217 (III) A, Universal Declaration of Human Rights, art. 19 (Dec. 10, 1948).

262. Access to Foreign Law in Civil and Commercial Matters, Recommendation 8, Hague CONFERENCE ON Private InTERnational LaW, https://assets.hcch.net/upload/foreignlaw_concl_e.pdf [https://perma.cc/YBX8-GGHA].

263. See, e.g., Scott A. Schumacher, Sentencing in Tax Cases after Booker: Striking the Right Balance between Uniformity and Discretion, 59 ViLL. L. Rev. 563, 568 (2014), quoting Marvin FrankeL, Criminal Sentences: LaW Without Order 8 (1973); Remarks at the National Archives and Records Administration, 2009 DAily Comp. Pres. Doc. 388 (May 21, 2009), at 6; Karl S. Coplan, Legal Realism, 
The United States' founders were fully aware of the potential danger from inaccessible legislation; their mother country provided plenty of examples, from the Star Chamber to legislative bodies governing colonial affairs convened far from where their public records were located. ${ }^{264}$ As early as 1789 , the U.S. federal government required a copy of newly enacted session laws to be published in three public newspapers, and a copy of the laws to be given to federal senators and representatives and state governors. ${ }^{265}$ Today, federal law requires the publication of both the United States Statutes at Large and the United States Code (USC) ${ }^{266}$ and has traditionally granted public access to its statutes through the Federal Depository Library Program (FDLP).

I64 The FDLP dates its origins to 1813, when Congress passed a law ordering 200 copies of the House and Senate Journals to be sent to universities, libraries, historical societies, and various government offices. ${ }^{267}$ The Department of the Interior was in charge of distributing federal government materials to libraries from $1857^{268}$ to $1895 .{ }^{269}$ Since 1895 , the Government Printing (now Publishing) Office (GPO) has administered the program. ${ }^{270}$ Senators and representatives could add or remove libraries from the FDLP during the later 19th and early 20th centuries. ${ }^{271}$ Today, senators and representatives can still designate libraries as depositories, but there is a cap on total FDLP libraries, and only the superintendent of documents can strip a library of depository status. ${ }^{272}$

I65 The Printing Act of $1895^{273}$ established the FDLP as we know it today. ${ }^{274}$ Originally, all depositories had to accept copies of all federal government publications on a list created by the superintendent of documents, but since 1922, the superintendent has several lists of documents designed for different collection needs. ${ }^{275}$ FDLP libraries designated regional depositories must still accept all publi-

Innate Morality, and the Structural Role of the Supreme Court in the U.S. Constitutional Democracy, 86 Tul. L. Rev. 181, 185-86 (2011), citing Mass. Const. pt. 1, art. XXX; 149 Cong. Rec. 6216 (2003) (statement of Sen. Leahy). This saying is known well enough to be satirized. See, e.g., JoN WinOKUR, Return of the Portable Curmudgeon 111 (1995) (attributing the quip "The United States is a nation of laws, badly written and randomly enforced" to Frank Zappa).

264. Amicus Brief of Sixty-Six Library Ass'ns, supra note 165, at 16-17, citing 16 Car. 1 c. 10, 5 Statutes of the Realm 110, and The Declaration of IndePendence para. 6 (U.S. 1776).

265. Act of July 27, 1789, ch. 14, §2, 1 Stat. 68 (1789).

266. 1 U.S.C. $\$ 112$ (2016), https://www.govinfo.gov/app/collection/USCODE [https:// perma.cc/F7ZL-BWF9] (requiring the Archivist of the United States to arrange for the Statutes at Large's publication); id. $\$ 202$ (requiring the House of Representatives Judiciary Committee to supervise the USC's publication).

267. J. Res. 1, 13th Cong., 3 Stat. 140 (1813); Snapshots of the FDLP, Fed. Depository LibraRY Program, https://www.fdlp.gov/about-the-fdlp/mission-and-history/2500-snapshots-of -the-fdlp-august-2000 [https://perma.cc/W3D9-FAA9].

268. J. Res. 5, § 1, 34th Cong., 11 Stat. 253 (1857).

269. Printing Act of 1895, ch. 23, \$64, 28 Stat. 601, 611 (1895).

270. Id. $\$ 61,28$ Stat. at 610; Snapshots of the FDLP, supra note 267.

271. J. Res. 5, 35th Cong., 11 Stat. 368 (1858); Act of Feb. 5, 1859, ch. 22, § 5, 11 Stat. 379, 380 (1859); Snapshots of the FDLP, supra note 267.

272. 44 U.S.C. $\$ \$ 1905,1909,1910,1912$ (2015), https://www.govinfo.gov/content/pkg/US CODE-2015-title44/pdf/USCODE-2015-title44-chap19.pdf [https://perma.cc/MF75-DFXT]; Law of June 23, 1913, ch. 3, 38 Stat. 4, 75 (1913); Snapshots of the FDLP, supra note 267. Senators and Representatives can ask for the cap to be raised, but must justify the decision. 44 U.S.C. $\$ 1905$.

273. 28 Stat. 601 (1895).

274. Snapshots of the FDLP, supra note 267.

275. Depository Collection and Development, Fed. Depository Library Program, https:// 
cations on all the superintendent's lists. ${ }^{276}$ Other depositories must take all publications on the superintendent's "FDLP Basic Collection" list, but otherwise may select which publications they accept. ${ }^{277}$ The superintendent of documents may ask for as many print copies of government publications as he or she deems necessary to distribute to libraries registered as federal depositories. ${ }^{278}$ There are over 1100 Federal Depository Libraries, including 46 regional depositories. ${ }^{279}$ All depositories must allow the public cost-free access to FDLP documents. ${ }^{280}$

I66 Title 44 of the USC specifies some publications that must be provided to the FDLP, but neither the USC nor the Statutes at Large are on that list. ${ }^{281}$ Both the USC and the Statutes at Large are currently on the "FDLP Basic Collection" list, which government agencies must provide. ${ }^{282}$ Both publications are on the GPO's "essential titles" list of publications that the FDLP will continue to distribute in physical format as long as they are available. ${ }^{283}$

I67 This part of the USC also mandates that at least some federal publications must be made available online. ${ }^{284}$ Although neither the USC nor the Statutes at Large are explicitly included in this mandate, the GPO used its authorized discretion to include them in the list of publications that must be available online. ${ }^{285}$

www.fdlp.gov/requirements-guidance/guidance/14-depository-collection-and-development [https:// perma.cc/D4K4-5SZB]. On March 15, 2018, U.S. Rep. Gregg Harper introduced the FDLP Modernization Act of 2018, H.R. 5305, 115th Cong. (2018). H.R. 5305-FDLP Modernization Act of 2018, CoNGRESS.GOV, https://www.congress.gov/bill/115th-congress/house-bill/5305/cosponsors?q= \%7B\%22search\%22\%3A\%5B\%22hr5305\%22\%5D\%7D\&r=1 (last visited Mar. 11, 2019). This bill, if it passes, would allow FDLP libraries to meet their collection requirements entirely with digital documents as long as they provide the public with fee-free access to those electronic resources. H.R. 5305, $\$ \$ 1741-1742$. The bill would also require the GPO to establish a "trustworthy information system and online repository" that the public could use for free to access federal materials distributed under the FDLP. Id. $\$ 1731$.

276. Lisa Peet, Industry: GPO Announces Plans to Update FDLP Rules, LiBR. J., Sept. 15, 2017, at 16-17, 2017 WLNR 28106218; Snapshots of the FDLP, supra note 267, citing Act of Mar. 20, 1922, ch. 103, 42 Stat. 422,436 (1922).

277. Snapshots of the FDLP, supra note 267. The DLC's draft 2017 recommendations suggest discarding lists such as the "Basic Collection" and replacing them with a mechanism that allows depository libraries to select only the publications they need. Depository Collection and Development, supra note 275.

278. 44 U.S.C. $\$ \$ 1903,1905$ (2015), https://www.govinfo.gov/app/collection/USCODE [https:// perma.cc/F7ZL-BWF9].

279. Gov't Publ'g Office, Federal Depository Library Directory (FDLD), Catalog of U.S. Gov'т PUBL'Ns (CGP), https://catalog.gpo.gov/F?RN=206986818 [https://perma.cc/Q4ZK-EXFJ] (search for [All FDLs] by checking that box at bottom of screen and select "Find all Regional Libraries" link).

280. 44 U.S.C. $\$ 1911$ (2015), https://www.govinfo.gov/app/collection/USCODE [https://perma.cc /F7ZL-BWF9].

281. Id. \$1903.

282. Id. $\$ 1$ 1905; Superintendent of Documents, Gov't Publ'g Office, FDLP Basic Collection, Fed. Depository Library Program, https://www.fdlp.gov/requirements-guidance-2/collections-and -databases/1442-basic-collection [https://perma.cc/A7W8-WEDE].

283. Essential Titles for Public Use in Paper or Other Tangible Format, Fed. Depository Library Program, https://www.fdlp.gov/requirements-guidance-2/collections-and-databases/1443 -essential-titles [https://perma.cc/UR5K-BTH7] (select [All] from "Show ... entries" pulldown menu).

284. 44 U.S.C. $\$ 4101$ (2015), https://www.govinfo.gov/app/collection/USCODE [https://perma.cc /F7ZL-BWF9].

285. U.S. Superintendent of Documents, Public Policy Statement 2016-2: Content SCOPE FOR GPO's System OF ONLINE ACCEss, https://www.fdlp.gov/file-repository/about-the-fdlp/poli cies/superintendent-of-documents-public-policies/2738-content-scope-for-gpo-s-system-of-online -access/file [https://perma.cc/8N7W-QSBY]. 
Members of the public can access these works through GPO's website Govinfo .gov. $^{286}$

I68 GPO authenticates publications it posts to its websites. ${ }^{287}$ After it confirms a document is valid, GPO uses a digital certificate to attach a digital signature to the document. ${ }^{288}$ A researcher can then use Adobe Acrobat or Adobe Reader version 7.0 or above to verify the signature and validate the chain of custody. ${ }^{289}$ After it certifies and digitally signs a document, GPO also adds a visible Seal of Authenticity that certifies that the document has not been altered since GPO authenticated it. $^{290}$

\section{The Internet, Public Access to the Law, and UELMA}

I69 By the late 20th century, published state statutes in the United States had reached a comfortable status. Most states had a print statutory code, either published by the government or by a private publisher, updated with annual or biennial pocket parts and session law services. The sets were far too expensive for most people outside of libraries or legal professionals to buy, but someone who wanted to research the law could go to the local law library (or large public or academic library) to access the code, and it was easy to know whether what you were reading was authentic.

I70 The Internet smashed that status quo; now, anyone with a connection could potentially access the entire body of law, including those statutes, from the comfort of his or her home, even if that home was hours away from the nearest law library. This new freedom of access, however, came with new issues. How would a person reading statutes online know that the text on a website was authentic? Would the code be available on a free website or only locked behind pay-walled databases, replacing the expense of obtaining a print set with the expense of subscribing to an online service?

\section{UELMA}

I71 All states make their statutory code and session laws available online. Some states have stopped publishing an official print version of their statutes. ${ }^{291} \mathrm{~A}$ few states, however, ensure that the online version of their statutes is an authoritative source available to the public and that those online statutes will remain available. Electronic information can be unintentionally or deliberately changed in ways the

286. Govinfo.Gov, https://www.govinfo.gov/ [https://perma.cc/B372-3WPH].

287. Authentication, U.S. Gov't PuBL'G OfFice, https://www.gpo.gov/authentication/ [https:// perma.cc/JPW9-DALA]. The proposed FDLP Modernization Act of 2018 would require the GPO to authenticate documents it provides online " $[\mathrm{t}] \mathrm{o}$ the greatest extent practicable." H.R. 5305, supra note $275, \S 1732(a)$.

288. Timothy L. Coggins \& Sarah G. Holterhoff, Authenticating Digital Government Information, in Government Information Management in the 21st Century: International Perspectives 133, 141 (Peggy Garvin ed., 2011), http://scholarship.richmond.edu/law-faculty-publications/953/ [https://perma.cc/2CZ3-LKLB].

289. Id.

290. Id. Interestingly, Govinfo.gov still warns viewers to "verify their results against the printed version." United States Code, Govinfo.Gov, https://www.govinfo.gov/app/collection/US CODE [https://perma.cc/DYB9-TZWF].

291. UELMA, supra note 7. 
reader cannot easily detect, ${ }^{292}$ but only a couple of states currently provide ways for the user to verify that this has not happened with his or her online statutes. As recently as 2013, fewer than 10 states designated their online statutes as official versions, promised to preserve old versions, or guaranteed public access; only two authenticated their online statutes. ${ }^{293}$ Virginia, regrettably, is one of the states lacking in all these areas.

I72 The Uniform Law Commission created UELMA to address this problem. UELMA creates a framework that states can use to ensure that their online legal materials, including statutes, are authentic, available to the public, and preserved for the future. ${ }^{294}$ UELMA does not require a state to publish its laws in a specific format. ${ }^{295}$ If, however, a state that enacts UELMA publishes its statutes only electronically, it must designate that electronic version an official version ${ }^{296}$ and authenticate its online statutes so that a reader can determine whether the version being read has been altered from the official version. ${ }^{297}$ Whoever is an official publisher of electronic statutes in a state that has enacted UELMA must also "ensure that the material is reasonably available for use by the public on a permanent basis." ${ }^{298}$ As of March 2019, 19 states and the District of Columbia have passed UELMA, and 3 more state legislatures have introduced legislation to enact it. ${ }^{299}$

\section{Delaware}

I73 Delaware enacted UELMA on July $23,2014,{ }^{300}$ and quickly took steps to follow that law's mandates and principles. All of the state's governmental entities must receive online access to its statutory code but can still request printed copies. ${ }^{301}$ Delaware says that the version of the statutory code available on the state government website is official. ${ }^{302}$ Since this online edition is official, the state must provide an

292. $I d$.

293. State Online Legal Information, AM. Ass'N of LAW Libraries, http://community.aallnet .org/digitalaccesstolegalinformationcommittee/stateonlinelegalinformation [https://perma.cc/B5HF $-3 \mathrm{EVC}]$.

294. The Uniform Electronic Legal Material Act: A Summary, UnIF. LAw CoMm'N, https://www.uni formlaws.org/HigherLogic/System/DownloadDocumentFile.ashx?DocumentFileKey=e509ddc6 -04c6-6c67-bcc5-6b5cb91d4ba7\&forceDialog=0 [https://perma.cc/BJ9G-2JBM].

295. Unif. Electronic Legal Material Act (UELMA) $\$ 4$ cmt. (Unif. Law Comm’n 2011).

296. Id. \$ 4(a)(1).

297. Id. $\$ 5$. As a side benefit, online state codes meeting these standards can also be cited in Bluebook format as though they were the print source. The Bluebook: A Uniform System of CitATiON R. 18.2.1(a), at 180 (Columbia Law Review Ass'n et al. eds., 20th ed. 2015).

298. Unif. Electronic Legal Material Act (UELMA) $₫ 8$ (Unif. Law Comm’n 2011). The state, however, does not have to provide cost-free public access. UELMA states only that what is "reasonable" should be determined "in a manner consistent with other state practice." $I d . \$ 8 \mathrm{cmt}$.

299. Electronic Legal Material Act, supra note 246.

300. Act of July 23, 2014, 79 Del. Laws ch. 357 (2013-2014), http://delcode.delaware.gov /sessionlaws/ga147/chp357.pdf [https://perma.cc/CGT3-K5BA], codified at 1 DeL. CoDE \$\$ 401-411, http://delcode.delaware.gov/title1/title1.pdf [https://perma.cc/22JA-NQPS].

301. 1 DeL. CoDE $\$ 108$, http://delcode.delaware.gov/title1/title1.pdf [https://perma.cc/22JA -NQPS].

302. See The Delaware Code Online, STATE OF DeL., http://delcode.delaware.gov/ [https://perma .cc/6NSX-2UTA] ("NOTICE: The Delaware Code appearing on this site . . is considered an official version of the State of Delaware statutory code."). 
authenticated version of the code ${ }^{303}$ that it preserves, ${ }^{304}$ and it must also make the online code "reasonably available for use by the public on a permanent basis." ${ }^{305}$ The state's website for the Code of Delaware gives the researcher the option to download an authenticated PDF of each title of the code, but not for individual sections. Similar to the federal GPO, Delaware uses digital certificates, signatures, and seals to certify documents as authentic. ${ }^{306}$ Although the state has made some strong first steps, it still has a way to go. The website currently offers only the Delaware Code currently in force, with no way to search older editions. The state also offers authenticated PDFs of session laws, ${ }^{307}$ but it has not deemed those PDFs official versions and seems to authenticate PDFs only once the legislature's two-year session is finished.

\section{Conclusion}

I74 The art of publicizing legislation has taken many turns throughout the ages. In some nations, such as Babylonia, Rome, Greece, and China, the early stages focused on posting the laws in public gathering places. Motives varied from selfaggrandizement to a genuine desire for informed citizens to a reluctant concession. It was easy to authenticate these early posted laws, although accessibility could be a problem. Citizens had to go to specific locations, often spread over the city, to research the law. In England's and Virginia's early days, public verbal announcements potentially allowed even illiterate citizens to know what the law said, but language could still be a barrier, and to access the law one had to be in the right place at the right time.

I75 Written codes on paper allowed authentic copies of the law to be distributed to more people, although only to a certain point-manuscript copies took time, and reproduction errors were likely. The advent of printing technology made it easier for a wider range of the public to receive authentic copies of the law. Often, the greatest obstacle toward publicizing the law was not technology but the government itself. Roman, English, and Virginian law entered multiple states of disarray due to government inaction. Fortunately, governments also provided a solution through initiatives to organize the law that included ways to make the law easier for citizens to access.

I76 The Internet era is the next stage in this story. As with the printing press, a technology has arrived that can greatly increase the public's access to authentic copies of the law. As with rulers dating back to ancient Babylonia, governments have expressed a desire to provide that access, although motivations may have changed over the years. The U.S. federal government has shown that it is possible to provide permanently and freely accessible, authenticated online copies of statutes. UELMA creates a framework for states to apply the principles of authenticated and permanent online access to their own statutes. States that have not already enacted this act should take the lead of generations of rulers before them and enact UELMA.

303. 1 DeL. CODE $\$ 405$, http://delcode.delaware.gov/title1/title1.pdf [https://perma.cc/22JA -NQPS].

304. Id. $\$ 407$.

305. Id. $\$ 408$.

306. Coggins \& Holterhoff, supra note 288 , at 142-43.

307. Id. 
I77 Online statutes may be less tangible than the forms in which legislation has been published in the past, whether in stone, bamboo, paper, or iron. By passing UELMA and following its outlines, though, state legislatures can follow in the grand tradition of Hammurabi, Zi Chan, Theodosius II, Justinian, Solon, Henry I, Thomas Jefferson, and many others by making the law a work that can be viewed by the public, now and in the future. 